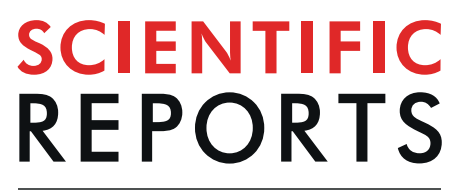

natureresearch

Check for updates

\title{
The greenhouse gas offset potential from seagrass restoration
}

\author{
Matthew P. J. Oreska ${ }^{1} \llbracket$, Karen J. McGlathery ${ }^{1}$, Lillian R. Aoki ${ }^{1,2}$, Amélie C. Berger ${ }^{1}$, \\ Peter Berg ${ }^{1} \&$ Lindsay Mullins ${ }^{1,3}$
}

Awarding $\mathrm{CO}_{2}$ offset credits may incentivize seagrass restoration projects and help reverse greenhouse gas (GHG) emissions from global seagrass loss. However, no study has quantified net GHG removal from the atmosphere from a seagrass restoration project, which would require coupled $C_{\text {org }}$ stock and GHG flux enhancement measurements, or determined whether the creditable offset benefit can finance the restoration. We measured all of the necessary GHG accounting parameters in the 7- $\mathrm{km}^{2}$ Zostera marina (eelgrass) meadow in Virginia, U.S.A., part of the largest, most cost-effective meadow restoration to date, to provide the first seagrass offset finance test-of-concept. Restoring seagrass removed 9,600 $\mathrm{tCO}$ from the atmosphere over 15 years but also enhanced both $\mathrm{CH}_{4}$ and $\mathrm{N}_{2} \mathrm{O}$ production, releasing $950 \mathrm{tCO}_{2} \mathrm{e}$. Despite tripling the $\mathrm{N}_{2} \mathrm{O}$ flux to $0.06 \mathrm{~g} \mathrm{~m}^{-2} \mathrm{yr}^{-1}$ and increasing $\mathrm{CH}_{4} 8$-fold to $0.8 \mathrm{~g} \mathrm{~m}^{-2}$ $\mathrm{yr}^{-1}$, the meadow now offsets $0.42 \mathrm{tCO}_{2} \mathrm{e} \mathrm{ha}^{-1} \mathrm{yr}^{-1}$, which is roughly equivalent to the seagrass sequestration rate for GHG inventory accounting but lower than the rates for temperate and tropical forests. The financial benefit for this highly successful project, $\$ 87 \mathrm{~K}$ at $\$ 10 \mathrm{MtCO}_{2} \mathrm{e}^{-1}$, defrays $\sim 10 \%$ of the restoration cost. Managers should also consider seagrass co-benefits, which provide additional incentives for seagrass restoration.

Seagrass meadows have been identified as important sinks in the global carbon cycle, because they are highly productive systems that bury organic carbon $\left(\mathrm{C}_{\text {org }}\right)^{1-4}$. Seagrass meadows potentially contain $4,200-8,400 \mathrm{Tg} \mathrm{C}_{\text {org }}$ in bed sediments and an additional $151 \mathrm{Tg} \mathrm{C}_{\text {org }}$ in above- and belowground biomass ${ }^{5}$-a significant global carbon stock threatened by accelerating seagrass habitat loss from coastal development, eutrophication, climate change, and other anthropogenic impacts ${ }^{6,7}$. Seagrass bed erosion following meadow collapse accelerates oxidation and remineralization of this sediment $\mathrm{C}_{\text {org }}{ }^{8-10}$. Global meadow loss may, therefore, release 50-330 $\mathrm{Tg} \mathrm{CO}_{2} \mathrm{yr}^{-1} \mathrm{back}$ to the atmosphere ${ }^{11}$. Seagrass restoration transfers $C_{\text {org }}$ back to the sediment ${ }^{9,12,13}$. However, despite increasing interest in seagrass 'blue carbon' and studies reporting seagrass sediment $\mathrm{C}_{\text {org }}$ stocks ${ }^{5,13-15}$, including several from restored meadows ${ }^{13,16,17}$, a study has yet to quantify the net greenhouse gas (GHG) removal from the atmosphere resulting from a seagrass restoration project ${ }^{18}$. Tokoro et al. ${ }^{3}$ provide, perhaps, the closest approximation, a net GHG removal estimate for natural seagrass meadows based on carbon flux measurements and a one-time sediment $\mathrm{C}_{\text {org }}$ burial rate. However, identifying the creditable $\mathrm{GHG}$ offset benefit requires isolating seagrass-enhanced $\mathrm{C}_{\text {org }}$ sequestration over time ${ }^{18}$, accounting for sequestered $\mathrm{C}_{\text {org }}$ turnover ${ }^{19}$, and determining whether seagrass presence also increases $\mathrm{GHG}$ emissions of $\mathrm{CH}_{4}, \mathrm{~N}_{2} \mathrm{O}$, and $\mathrm{CO}_{2}$ evasion associated with $\mathrm{CaCO}_{3}$ buried in seagrass sediment, all of which would reduce the GHG benefit from seagrass-enhanced carbon sequestration ${ }^{20-22}$. Seagrass GHG flux measurements, coupled with repeated measurements of $\mathrm{C}_{\text {org }}$ stock enhancement over time to account for $\mathrm{C}_{\text {org }}$ turnover within sediment and biomass carbon pools (i.e., GHG 'stock change'), would enable calculation of seagrass-enhanced sequestration; however, there are questions about the feasibility of applying a stock change approach in a seagrass system ${ }^{18}$.

Prospective seagrass restoration projects currently face uncertainty about the magnitude of the GHG offset benefit they can generate, and perhaps as a result, a seagrass project has not yet applied for voluntary carbon offset-credits to help finance additional seagrass restoration ${ }^{23}$. Seagrass projects have been eligible to receive offset-credits since 2015, when the Verified Carbon Standard Program (the VCS, now administered by Verra) published the first seagrass offset-credit accounting framework, VM0033: Methodology for Tidal Wetland and Seagrass Restoration ${ }^{24}$. The framework has been used by countries seeking to incorporate seagrass meadows into national GHG inventories but not by individual projects. Under this methodology, the certifiable GHG offset benefit only corresponds to the net $\mathrm{CO}_{2}$ (or $\mathrm{CO}_{2}$ equivalent GHG: $\mathrm{CO}_{2} \mathrm{e}$ ) removal from the atmosphere that can

${ }^{1}$ Department of Environmental Sciences, University of Virginia, VA, USA. ${ }^{2}$ Department of Ecology and Evolutionary Biology, Cornell University, Ithaca, NY, USA. ${ }^{3}$ Department of Geosciences, Mississippi State University, Starkville, MS, USA. ${ }^{\circledR}$-mail: mpo4zx@virginia.edu 


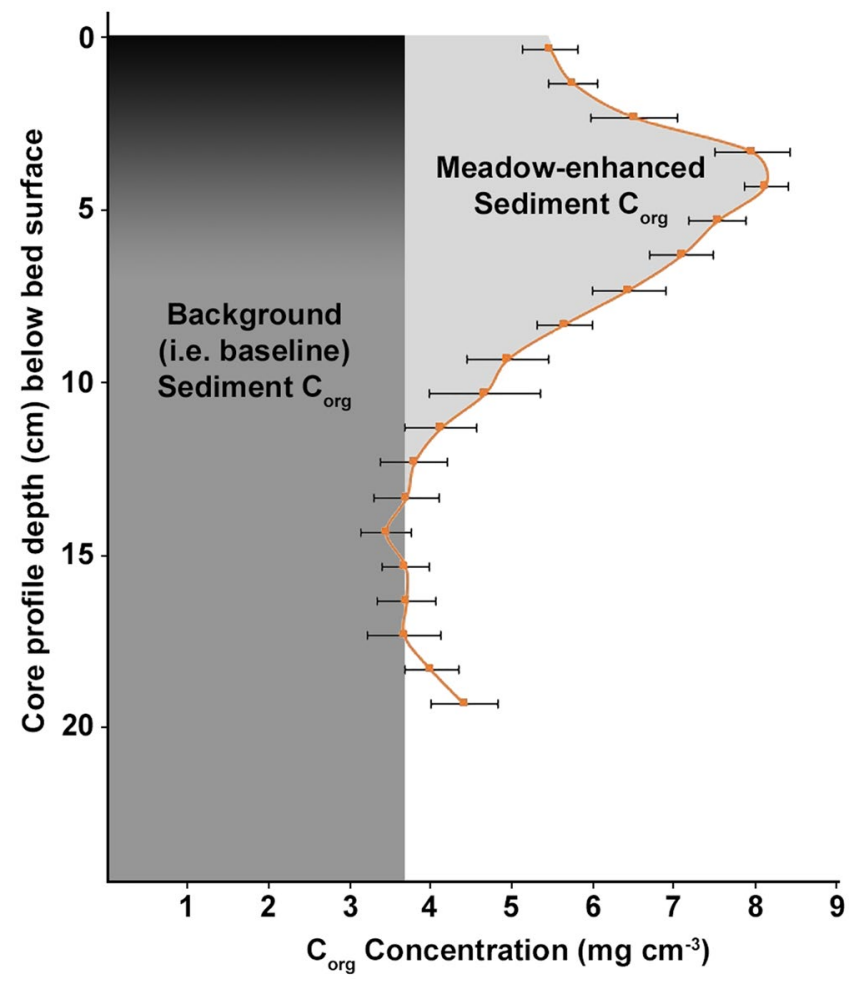

Figure 1. Seagrass meadow sediment $\mathrm{C}_{\text {org }}$ concentrations are typically highest below the surface in a region corresponding with the rhizosphere and approach the background concentration observed at unvegetated sites with increasing depth (data adapted from Greiner et $a l .{ }^{12}$ and used with permission). The seagrass-enhanced sediment $\mathrm{C}_{\text {org }}$ stock (light gray) can be quantified by integrating the area under the profile and subtracting the background $\mathrm{C}_{\text {org }}$ stock that one would expect to find absent the meadow (dark gray); note that this approach does not require establishing a reference plane or quantifying bed accretion (black gradient) attributable to the meadow by sediment dating.

be directly attributed to a restoration project in a recognized carbon pool (i.e., negative emissions over time), minus any GHG emission increases. It is important to emphasize that this enhanced sequestration equals the $\mathrm{CO}_{2}$ sequestered by the restoration project (i.e., the 'with project' scenario) minus the background sequestration that would occur if the project did not exist (i.e., in the status quo baseline: the 'without project' scenario) ) $^{24,25}$. The former can be measured directly; the latter must be estimated by extrapolating pre-project conditions or by comparing project and control sites over time.

For seagrass restoration projects, the net GHG benefit equals $\mathrm{CO}_{2}$ sequestrated as enhanced sediment $\mathrm{C}_{\text {org }}$ (see Fig. 1: gross meadow sediment stock minus an equivalent area bare sediment stock) and the long-term average $\mathrm{C}_{\text {org }}$ sequestered in above- and belowground biomass within the project area, minus any enhanced GHG production ${ }^{24,25}$-specifically $\mathrm{CH}_{4}, \mathrm{~N}_{2} \mathrm{O}$, and $\mathrm{CO}_{2}$ evasion associated with $\mathrm{CaCO}_{3}$ buried in seagrass sediment ${ }^{20-22,26}$. Community respiration does not affect the GHG offset benefit for meadow restoration projects, because $\mathrm{CO}_{2}$ fixed through photosynthesis and then returned to the atmosphere through respiration is not a net flux of $\mathrm{CO}_{2}$ to the atmosphere. Enhanced respiration could, however, adversely affect a seagrass conservation project attempting to avoid the remineralization of sequestered $\mathrm{C}_{\text {org }}$ stocks. As noted above, the offset benefit from seagrass biomass sequestration over interannual timescales corresponds to the average, annual standing biomass stock, not peak biomass. This average reflects loss and turnover due to herbivory, senescence, export, and, in some cases, harvest or other disturbances. Some of the exported seagrass carbon may remain sequestered at deep ocean depositional $\operatorname{sites}^{27}$, and some is deposited along the coastline as wrack on beaches, marshes, and on tidal flats. The VCS and other offset crediting standards conservatively assume that exported biomass is decomposed and returns to the atmosphere as $\mathrm{CO}_{2}$.

The offset-credit methodology recommends measuring the sediment $\mathrm{C}_{\text {org }}$ stock repeatedly over time to quantify sequestered $\mathrm{C}_{\text {org }}$ enhancement (i.e., stock change), rather than measuring the $\mathrm{C}_{\text {org }}$ stock to an arbitrary depth on a single occasion or estimating $\mathrm{C}_{\text {org }}$ accumulation from burial rates ${ }^{25}$. This is because seagrass sediment $\mathrm{C}_{\text {org }}$ stock estimates ${ }^{15,28,29}$ and burial rates ${ }^{2,30,31}$ likely overestimate net $\mathrm{CO}_{2}$ removal from the atmosphere due to uncertainties with dating techniques for sediment accretion over relatively short time scales (decades) ${ }^{18}$. These estimates also include allochthonous carbon $\left(\mathrm{C}_{\text {org }}\right.$ fixed outside the project area) that is excluded from GHG offset accounting methodologies and background $\mathrm{C}_{\text {org }}$ that would be sequestered in the area in the baseline scenario (see Supplement) ${ }^{18,32}$. This study shows how repeated stock change measurements can provide a more reliable approach for assessing how meadow presence enhances sediment $C_{\text {org }}$ accumulation and how 
remineralization, especially in the upper mixed layer of the sediment ${ }^{18,19,33}$, affects this $C_{\text {org }}$ to determine sequestration for offset-credit accounting ${ }^{34}$.

Uncertainty about how seagrass restoration affects $\mathrm{CH}_{4}$ and $\mathrm{N}_{2} \mathrm{O}$ fluxes represents a data gap for prospective restoration projects. The VCS defines the de minimis threshold at $<5 \%$ of the GHG benefit; fluxes of $\mathrm{CH}_{4}$ and $\mathrm{N}_{2} \mathrm{O}$ lower than this are discounted in offset accounting ${ }^{24}$. Given their higher global warming potentials relative to $\mathrm{CO}_{2}$, a marginal increase in either $\mathrm{CH}_{4}$ or $\mathrm{N}_{2} \mathrm{O}$ production could substantially reduce the net GHG benefit from meadow restoration ${ }^{35-37}$. Emissions of $\mathrm{CH}_{4}$ and $\mathrm{N}_{2} \mathrm{O}$ from seagrass systems were earlier assumed to be negligible ${ }^{38,39}$, because $\mathrm{H}_{2} \mathrm{~S}$ produced by sulfate reduction oxidizes $\mathrm{CH}_{4}$ in marine sediments ${ }^{40,41}$ and seagrass nitrogen demand limits $\mathrm{N}_{2} \mathrm{O}$ efflux ${ }^{42}$. Oremland ${ }^{43}$ and Moriarty et al. ${ }^{44}$ reported very low seagrass methane fluxes, and studies have documented high sulfate reduction in seagrass beds ${ }^{44-46}$. However, several recent studies have determined that $\mathrm{CH}_{4}$ and $\mathrm{N}_{2} \mathrm{O}$ enhancement partially offsets the 'blue carbon' benefit in mangrove and marsh systems ${ }^{37,47-49}$. A recent review found that $\mathrm{CH}_{4}$ fluxes in seagrass systems varied considerably, from 1.25-401.50 $\mu \mathrm{mol} \mathrm{CH} \mathrm{CH}^{-2} \mathrm{~d}^{-1}$, and were lower on average than mangrove and salt marsh habitats ${ }^{48}$ (Table 1). One study has suggested that seagrass sediments may limit $\mathrm{N}_{2} \mathrm{O}$ release (Table 2), but the only available $\mathrm{N}_{2} \mathrm{O}$ data from a seagrass system derives from sediment core incubations ${ }^{50}$.

Without adequate data to quantify the net GHG benefit from seagrass restoration, the VCS allows projects to use the emission factor for seagrass established by the Intergovernmental Panel on Climate Change (IPCC) for national GHG inventory accounting, $0.43 \mathrm{t} \mathrm{C} \mathrm{ha}^{-1} \mathrm{yr}^{-151}$, even in areas where regional or local estimates for some parameters are available ${ }^{24,34}$. This default factor may over/underestimate the net GHG benefit. The number derives from only two studies of Posidonia oceanica, a seagrass species that generates unusually high sediment $\mathrm{C}_{\text {org }}$ stocks, and does not account for the baseline sediment $\mathrm{C}_{\text {org }}$ stock, allochthonous carbon, or the enhancement of GHG fluxes ${ }^{52,53}$

This study is the first study to calculate net GHG removal by a seagrass restoration project based on measured data for all of the parameters required by the VCS accounting framework ${ }^{23,24}$, making this the first verification that seagrass systems provide a creditable GHG offset benefit. We leveraged the long-term seagrass restoration and monitoring effort in the Virginia, U.S.A., coastal bays, which is acknowledged as the world's largest successful seagrass restoration to date. Our study focused on the $7 \mathrm{~km}^{2}$ Zostera marina (eelgrass) meadow in South Bay (Fig. 2). We undertook this work to address two urgent GHG accounting questions: 1) does seagrass restoration increase GHG fluxes that adversely impact the net GHG benefit, and 2) is the IPCC seagrass restoration default factor conservative for GHG accounting ${ }^{51}$ ? No other study has attempted to apply these comprehensive GHG accounting methods to a seagrass system before. This study, therefore, establishes a benchmark for expectations about seagrass 'blue carbon' finance potential, because the South Bay meadow likely remains the least expensive meadow restoration on a cost per area basis ${ }^{17,54}$. It represents a best-case scenario for potentially financing restoration through offset-crediting.

\section{Results}

Enhanced carbon sequestration. With repeated stock change measurements, we observed significant $\mathrm{C}_{\text {org }}$ stock enhancement at the meadow scale resulting from increasing $\mathrm{C}_{\text {org }}$ concentrations within the bed, seagrass-enhanced bed accretion, and meadow expansion. The meadow-wide, net sediment $\mathrm{C}_{\text {org }}$ sequestration attributable to the restoration increased from 1,130 t C org in 2013 to 2,010 $\mathrm{t}$ in 2016 (Table 3; Fig. 3). Note that these values are stocks relative to a known baseline that represents the 'without restoration project' scenario, not rates, which can be obtained by dividing the stock by a time interval. Approximately $280 \mathrm{t}$ of this $880 \mathrm{t} \mathrm{C}_{\text {org }}$ stock increase occurred in the top $2 \mathrm{~cm}$ of the bed, which was likely deposited between 2013 and 2016 (see Supplement discussion of accretion); the remaining $600 \mathrm{t}$ accumulated within the bed between 2013 and 2016. The 2013 meadow stored an average of $196 \mathrm{~g} \mathrm{C}_{\text {org }} \mathrm{m}^{-2}$ and the 2016 meadow stored an average of $292 \mathrm{~g} \mathrm{C}_{\text {org }} \mathrm{m}^{-2}$. The 2013 enhanced stock took 12 years to accumulate. Between 2013 and 2016, the enhanced sediment $\mathrm{C}_{\text {org }}$ stock almost doubled, indicating that the sequestration rate also increased. Meadow $\mathrm{C}_{\text {org }}$ sequestration in sediments was $346 \mathrm{t}$ $\mathrm{CO}_{2} \mathrm{yr}^{-1}$ from 2001-2013 and $1070 \mathrm{t} \mathrm{CO}_{2} \mathrm{yr}^{-1}$ from 2013-2016.

The average aboveground biomass standing stock over three years was $109 \mathrm{gdw} \mathrm{m}^{-2}$, equivalent to approximately $40.5 \mathrm{~g} \mathrm{C}_{\text {org }} \mathrm{m}^{-2}$. This reflects seasonal fluctuations that ranged from $330 \mathrm{~g}$ dry weight $(\mathrm{gdw}) \mathrm{m}^{-2}$ in August $\left(201.4 \pm 29 \mathrm{~g}\right.$ live plus $129.7 \pm 15 \mathrm{~g}$ dead) to $38.5 \mathrm{gdw} \mathrm{m}^{-2}$ in March $(19.58 \pm 4.8 \mathrm{~g}$ live plus $18.86 \pm 2.4 \mathrm{~g} \mathrm{dead})$ (see Supplement). All reported errors relate standard errors (SE), unless otherwise stated. The average aboveground biomass shoot ${ }^{-1}$ was $0.4 \pm 0.07 \mathrm{gdw}$. Multiplying the average annual biomass per shoot by the interpolated average annual density values and integrating over the meadow area yielded an aboveground biomass standing stock of 710 t CO$_{2}$ in 2013 and 810 t CO$_{2}$ in 2016, due to meadow expansion. This standing stock is the average amount of $\mathrm{C}_{\text {org }}$ held in seagrass biomass throughout the year and is less than a third of the peak biomass in summer. Live belowground biomass ranged from $35.51 \pm 7.3 \mathrm{gdw} \mathrm{m}^{-2}$ in January to $95.26 \pm 13 \mathrm{gdw} \mathrm{m}^{-2}$ in August; the average annual live belowground biomass was $47.1 \mathrm{gdw} \mathrm{m}^{-2}$ (Supplement). Dead belowground biomass ranged from $91.03 \pm 17 \mathrm{gdw} \mathrm{m}^{-2}$ in June 2016 to $131.91 \pm 12 \mathrm{gdw} \mathrm{m}^{-2}$ in March, yielding an average, annual dead belowground biomass of $119 \mathrm{gdw} \mathrm{m}^{-2}$ (Supplement). Average, annual unit area estimates for live and dead belowground biomass were 16.0 and $40.4 \mathrm{~g} \mathrm{C}_{\mathrm{org}} \mathrm{m}^{-2}$, respectively. Multiplied by the respective meadow areas, the combined belowground biomass stock sequestered $1,200 \mathrm{t} \mathrm{CO}_{2}$ in 2013 and 1,520 t CO 2016 .

Sediment $\mathrm{C}_{\text {org }}$ represented the largest sequestered carbon pool in the meadow in both 2013 and 2016, accounting for $68.5 \%$ of the total GHG benefit in 2013 and more than three-quarters of the total GHG benefit in 2016 (Table 3). Annual belowground biomass (live + dead) accounted for $14.7 \%$ of the total 2016 sequestered stock, and aboveground biomass represented $8.4 \%$. Enhanced sediment $\mathrm{C}_{\text {org }}$ and the average, annual seagrass stock sequestered a combined 6,060 $\mathrm{t} \mathrm{CO}_{2}$ in 2013 and 9,590 $\mathrm{t} \mathrm{CO}_{2}$ in 2016 (Table 3). 


\begin{tabular}{|c|c|c|c|c|c|}
\hline Location & Seagrass & Method & $\begin{array}{l}\mathrm{CH}_{4} \text { Flux }(\mu \mathrm{mol} \\
\left.\mathrm{m}^{-2} \mathrm{hr}^{-1}\right)\end{array}$ & Notes & Reference \\
\hline Florida Keys, FL, USA & Thalassia testudinum & Benthic chambers and incubations & $1.81-1.86$ & & 43 \\
\hline Bimini, Bahama Island & Syringodium sp. & Benthic chambers and incubations & $0.14-0.47$ & & 43 \\
\hline Moreton Bay, Australia & Zostera capricorni & In vitro incubations & 14.5 & Est. for top $20 \mathrm{~cm}$ of bed & 44 \\
\hline Red Sea & $\begin{array}{l}\text { Multispecies: Thalassodendron } \\
\text { ciliatum, Cymodocea serrulata, } \\
\text { Halodule uninervis, etc. }\end{array}$ & Core incubations & $0.004-23.6$ & Salinity range $=37.98-42.29$ & 49 \\
\hline Ria Formosa Lagoon, Portugal & Zostera noltii & Benthic chambers & 4.4 & Aerial exposure at night & 82 \\
\hline Ria Formosa Lagoon, Portugal & Zostera noltii & Benthic chambers & 6.9 & Aerial exposure during day & 82 \\
\hline Ria Formosa Lagoon, Portugal & Zostera noltii & Benthic chambers & $9.0-30$ & During tidal flooding & 82 \\
\hline Ria Formosa Lagoon, Portugal & Zostera noltii & Benthic chambers & \multicolumn{2}{|c|}{$4.4-71($ mean $=12.8)$} & 82 \\
\hline Florida Bay, FL, USA & Thalassia testudinum & $\begin{array}{l}\text { Benthic chambers and porewater } \\
\text { samples }\end{array}$ & 0.567 & Dead seagrass areas in winter & 83 \\
\hline Florida Bay, FL, USA & Thalassia testudinum & $\begin{array}{l}\text { Benthic chambers and porewater } \\
\text { samples }\end{array}$ & 14.21 & Live seagrass areas in fall & 83 \\
\hline Cape Lookout Bight, NC, USA & Zostera marina and Halodule sp. & $\begin{array}{l}\text { Core extraction, centrifuging, } \\
\text { porewater sampling }\end{array}$ & $20-2000$ & $\begin{array}{l}\text { Seagrass not specifically studied but } \\
\text { occurs in the general study area }\end{array}$ & 84 \\
\hline Arcachon Bay, France & Zostera noltii & Benthic chambers & $1.6-32.7$ & $\begin{array}{l}\text { Sed-water flux with seasonal } \\
\text { variation }\end{array}$ & 85 \\
\hline Chilika Lagoon, India & $\begin{array}{l}\text { Multispecies: Halodule spp., } \\
\text { Halophila spp. }\end{array}$ & Open water and sediment samples & $4.17,5.6$ & Wet and dry season averages & 86 \\
\hline Tomales Bay, CA, USA & (Zostera marina) & Benthic chambers & 2.08 & Summer eelgrass bed & 87 \\
\hline Tomales Bay, CA, USA & (Zostera marina) & Benthic chambers & 0.896 & Winter eelgrass bed & 87 \\
\hline South Bay, VA, USA & Zostera marina & Benthic chambers & $13.110 \pm 4.570$ & Seagrass spring average & This study \\
\hline South Bay, VA, USA & Zostera marina & Benthic chambers & $3.136 \pm 1.307$ & Seagrass summer average & This study \\
\hline South Bay, VA, USA & Zostera marina & Benthic chambers & $0.845 \pm 0.255$ & Seagrass fall average & This study \\
\hline South Bay, VA, USA & Zostera marina & Benthic chambers & 5.697 & Seagrass 9-month average & This study \\
\hline South Bay, VA, USA & Zostera marina & Benthic chambers & $1.778 \pm 0.930$ & Bare spring average & This study \\
\hline South Bay, VA, USA & Zostera marina & Benthic chambers & $0.050 \pm 0.021$ & Bare summer average & This study \\
\hline South Bay, VA, USA & Zostera marina & Benthic chambers & $0.387 \pm 0.104$ & Bare fall average & This study \\
\hline South Bay, VA, USA & Zostera marina & Benthic chambers & 0.739 & Bare 9-month average & This study \\
\hline
\end{tabular}

Table 1. Reported $\mathrm{CH}_{4}$ flux data for seagrass systems.

The total, cumulative gross primary production (GPP) in the meadow from 2001-2013 was calculated to be $39,700 \mathrm{t} \mathrm{CO}_{2}$. By 2016, this estimate had increased to 84,900 t $\mathrm{CO}_{2}$, due to meadow expansion. Total, enhanced $\mathrm{C}_{\text {org }}$ sequestration was, therefore, $15.3 \%$ of cumulative GPP in 2013 and $11.3 \%$ in 2016.

Enhanced GHG emissions and the net GHG benefit. Seagrass presence significantly increased both the $\mathrm{CH}_{4}\left(\chi^{2}(1)=13.1, p<0.0003\right)$ and the $\mathrm{N}_{2} \mathrm{O}$ fluxes $\left(\chi^{2}(1)=8.46, p<0.004\right)$ (Fig. 4A,B; Table 4). There was seasonal variation with seagrass presence*month interaction significant for both $\mathrm{CH}_{4}\left(\chi^{2}(10)=36.4, p<7.08 \mathrm{e}\right.$ 5) and $\mathrm{N}_{2} \mathrm{O}$ release $\left(\chi^{2}(10)=35.8, p<9.09 \mathrm{e}-5\right)$. The seagrass $\mathrm{CH}_{4}$ flux was highest in June, $15.9 \pm 6.95$ (SE) $\mu \mathrm{mol} \mathrm{CH} \mathrm{CH}^{-2} \mathrm{hr}^{-1}$ and lowest in August, $0.32 \pm 0.22$ (SE) $\mu \mathrm{mol} \mathrm{CH} \mathrm{CH}_{4}^{-2} \mathrm{hr}^{-1}$. The October 2016 flux was also low, $0.38 \pm 0.06$ (SE) $\mu \mathrm{mol} \mathrm{CH} \mathrm{Cm}^{-2} \mathrm{hr}^{-1}$. The average bare site $\mathrm{CH}_{4}$ flux ranged from $3.37 \pm 1.60$ (SE) $\mu \mathrm{mol} \mathrm{CH}_{4}$ $\mathrm{m}^{-2} \mathrm{hr}^{-1}$ in April to $0.01 \pm 0.007$ (SE) $\mu \mathrm{mol} \mathrm{CH} \mathrm{Cm}^{-2} \mathrm{hr}^{-1}$ in July. The average, annual enhanced $\mathrm{CH}_{4}$ flux was $0.70 \pm 0.46$ (SE) $\mathrm{g} \mathrm{CH}_{4} \mathrm{~m}^{-2} \mathrm{yr}^{-1}$. This represents the average, annual fluxes of $0.80 \pm 0.53(\mathrm{SE}) \mathrm{g} \mathrm{CH}_{4} \mathrm{~m}^{-2} \mathrm{yr}^{-1}$ from vegetated sites minus the average flux $\left(0.10 \pm 0.07(\mathrm{SE}) \mathrm{g} \mathrm{CH}_{4} \mathrm{~m}^{-2} \mathrm{yr}^{-1}\right)$ in bare sites (Fig. 4A; Table 1).

Bulk porewater $\mathrm{CH}_{4}$ concentrations measured at seagrass and bare sites in August and October yielded a negligible diffusive flux (Fig. 5). The highest average $\mathrm{CH}_{4}$ porewater concentration was $0.30 \pm 0.25 \mu \mathrm{mol} \mathrm{L}^{-1}$ at $1.5 \mathrm{~cm}$ below the sediment water interface at seagrass sites in October. The highest average concentrations in August were observed at $10.5 \mathrm{~cm}$ below the sediment water interface, $0.18 \pm 0.14 \mu \mathrm{mol} \mathrm{L}^{-1}$ at the bare sites and $0.19 \pm 0.06 \mu \mathrm{mol} \mathrm{L}^{-1}$ at the seagrass sites (Fig. 5). Assuming a sediment diffusivity of $0.1 \times 10^{-4} \mathrm{~cm}^{2} \mathrm{~s}^{-1}$ and using Fick's first law of diffusion, a $\mathrm{CH}_{4}$ concentration of $0.02 \mathrm{nmol} \mathrm{cm}{ }^{-3}$ gave a diffusive flux of $-0.007 \mu \mathrm{mol} \mathrm{m}^{-2} \mathrm{hr}^{-1}$. This flux was negligible compared to $\mathrm{CH}_{4}$ emissions captured in the water column and was therefore excluded from subsequent GHG accounting.

Average $\mathrm{N}_{2} \mathrm{O}$ fluxes in the seagrass meadow ranged from $0.67 \pm 0.42$ (SE) in April to $0.01 \pm 0.01$ (SE) $\mu \mathrm{mol}$ $\mathrm{N}_{2} \mathrm{O} \mathrm{m}^{-2} \mathrm{hr}^{-1}$ in August. $\mathrm{N}_{2} \mathrm{O}$ fluxes were also lower at bare sites, ranging from $0.21 \pm 0.14$ (SE) in April to $0.001 \pm 0.0004$ (SE) $\mu \mathrm{mol} \mathrm{N} \mathrm{O} \mathrm{m}^{-2} \mathrm{hr}^{-1}$ in July (Fig. 4B). The average, annual vegetated flux of $0.06 \pm 0.04$ (SE) $\mathrm{g} \mathrm{N}_{2} \mathrm{O} \mathrm{m}^{-2} \mathrm{yr}^{-1}$ minus the average, annual bare flux of $0.02 \pm 0.01$ (SE) $\mathrm{g} \mathrm{N}_{2} \mathrm{O} \mathrm{m}^{-2} \mathrm{yr}^{-1}$ yielded an enhanced flux of $0.04 \pm 0.03$ (SE) $\mathrm{g} \mathrm{N}_{2} \mathrm{O} \mathrm{m}^{-2} \mathrm{yr}^{-1}$ (Table 2). Scaling the trace GHG fluxes by meadow area over time and by their 100-year global warming potentials ${ }^{36}$, meadow-enhanced $\mathrm{CH}_{4}$ and $\mathrm{N}_{2} \mathrm{O}$ fluxes released 530 and $420 \mathrm{t} \mathrm{CO}_{2} \mathrm{e}$ between 2001-2016, respectively (Table 3; Fig. 6). 


\begin{tabular}{|l|l|l|l|l|l|}
\hline Location & Seagrass & Method & $\begin{array}{l}\mathbf{N}_{2} \mathbf{O ~ F l u x ~} \\
\left(\mu \mathbf{m o l ~ m}^{-2} \mathbf{h r}^{-1}\right)\end{array}$ & Notes & Reference \\
\hline Nanwan Bay, Taiwan & $\begin{array}{l}\text { Thalassia hemprichii, } \\
\text { Halodule uninervis }\end{array}$ & Sediment incubations & $0.3-2.2^{*}$ & 12 -hr incubations & 42 \\
\hline Lake Akkeshi, Japan & Zostera marina & Sediment incubations & $\left(0.009-0.022 \mu \mathrm{mol} \mathrm{L}^{-1}\right)$ & $\begin{array}{l}\text { Concentrations following } \\
7 \text {-day incubations }\end{array}$ & 50 \\
\hline South Bay, Virginia, USA & Zostera marina & Benthic chambers & $\mathbf{0 . 3 7 8} \pm \mathbf{0 . 1 8 4}$ & Seagrass spring average & This study \\
\hline South Bay, Virginia, USA & Zostera marina & Benthic chambers & $\mathbf{0 . 0 4 3} \pm \mathbf{0 . 0 1 3}$ & Seagrass summer average & This study \\
\hline South Bay, Virginia, USA & Zostera marina & Benthic chambers & $\mathbf{0 . 0 3 9} \pm \mathbf{0 . 0 0 7}$ & Seagrass fall average & This study \\
\hline South Bay, Virginia, USA & Zostera marina & Benthic chambers & $\mathbf{0 . 1 5 3}$ & Seagrass -month average & This study \\
\hline South Bay, Virginia, USA & Zostera marina & Benthic chambers & $\mathbf{0 . 1 2 0} \pm \mathbf{0 . 0 7 3}$ & Bare spring average & This study \\
\hline South Bay, Virginia, USA & Zostera marina & Benthic chambers & $\mathbf{0 . 0 0 3} \pm \mathbf{0 . 0 0 2}$ & Bare summer average & This study \\
\hline South Bay, Virginia, USA & Zostera marina & Benthic chambers & $\mathbf{0 . 0 4 6} \pm \mathbf{0 . 0 1 3}$ & Bare fall average & This study \\
\hline South Bay, Virginia, USA & Zostera marina & Benthic chambers & $\mathbf{0 . 0 5 7}$ & Bare 9-month average & This study \\
\hline
\end{tabular}

Table 2. Reported $\mathrm{N}_{2} \mathrm{O}$ flux data for seagrass systems. ${ }^{*} \mu \mathrm{mol}$ g wet $\mathrm{wt}^{-1} \mathrm{hr}^{-1}$.

We did not find a significant difference between average $C_{\text {inorg }}$ concentrations by paired depth horizon in bare and seagrass sediment cores $(t=-0.287, \mathrm{df}=13, p>0.389)$. Inorganic carbon concentrations in the top $12 \mathrm{~cm}$ of the bed were similar throughout the meadow (site $\mathrm{n}=16$ ), averaging $0.11 \pm 0.04 \mathrm{mg} \mathrm{C}_{\text {inorg }} \mathrm{cm}^{-3}$. Scaling our average concentration from the top $6 \mathrm{~cm}$ of the bare site, $0.13 \pm 0.04 \mathrm{mg} \mathrm{C}_{\text {inorg }} \mathrm{cm}^{-3}$, by meadow area gave estimated $\mathrm{CO}_{2}$ emissions from $\mathrm{CaCO}_{3}$ formation of $450 \mathrm{t} \mathrm{CO}_{2}$ in 2013 and $623 \mathrm{t} \mathrm{CO}_{2}$ by 2016. However, the absence of a significant difference in $\mathrm{CaCO}_{3}$ between bare and seagrass sites meant that there was no net $\mathrm{CO}_{2}$ evasion attributable to the seagrass restoration (Table 3), so seagrass-enhanced $\mathrm{CO}_{2}$ evasion from $\mathrm{CaCO}_{3}$ between 2001-2016 was zero.

Integrating both stock changes and fluxes, this seagrass meadow restoration generated a net GHG benefit, which increased from $0.21 \mathrm{t} \mathrm{C} \mathrm{ha}^{-1} \mathrm{yr}^{-1}$ between 2001-2013 to $0.42 \mathrm{t} \mathrm{C} \mathrm{ha}^{-1} \mathrm{yr}^{-1}$ from 2013-2016, 12-15 years after restoration started.

\section{Discussion}

By applying the VCS GHG accounting methodology for the first time to an actual seagrass restoration project ${ }^{24}$, this study confirms the generally accepted but essentially untested hypothesis that seagrass restoration results in net GHG removal from the atmosphere-a GHG offset benefit that can potentially finance restoration. We also found that seagrass presence increased both $\mathrm{CH}_{4}$ and $\mathrm{N}_{2} \mathrm{O}$ release, but these increases had a relatively small effect on the net GHG benefit. Although other studies have reported increases in gross seagrass bed sediment carbon concentrations following seagrass restoration (e.g. ${ }^{9,12}$ ), these reports do not translate directly to an offset benefit ${ }^{18}$. As we demonstrate in this study, gross $\mathrm{C}_{\text {org }}$ stocks determined in previous studies overestimate the GHG offset benefit, because they do not account for background $\mathrm{C}_{\text {org }}$ sequestration that would occur in the absence of seagrass or GHG flux increases due to meadow restoration. All of these parameters must be known to determine the GHG offset benefit provided by seagrass restoration. This study also demonstrates the utility of the stock change approach for seagrass GHG offset accounting and addresses questions about stock change feasibility ${ }^{18}$.

Seagrass-effects on $\mathrm{CH}_{4}$ and $\mathrm{N}_{2} \mathrm{O}$ release. The enhanced $\mathrm{CH}_{4}$ emissions reported here marginally exceeded the de minimis threshold, as defined by the VCS (<5\%), reducing the total GHG benefit by $5.5 \%$ in 2013 and by $5.6 \%$ in 2016 . By comparison, Rosentreter et al. ${ }^{47}$ estimated a $20.5 \%$ offset for methanogenesis in a tropical Australian mangrove forest. The enhanced $\mathrm{N}_{2} \mathrm{O}$ flux for the seagrass restoration was technically de minimis, $4.7 \%$ in 2013 and $4.4 \%$ in 2016 . However, it is important to note that both seagrass trace gas fluxes reported here, $0.695 \mathrm{~g} \mathrm{CH}_{4} \mathrm{~m}^{-2} \mathrm{yr}^{-1}$ and $0.037 \mathrm{~g} \mathrm{~N}_{2} \mathrm{O} \mathrm{m}^{-2} \mathrm{yr}^{-1}$, exceeded the conservative general default factors for net benefit accounting, $0.56 \mathrm{~g} \mathrm{CH}_{4} \mathrm{~m}^{-2} \mathrm{yr}^{-1}$ (for salinities>20 ppt) and $0.016 \mathrm{~g} \mathrm{~N}_{2} \mathrm{O} \mathrm{m}^{-2} \mathrm{yr}^{-1}$ (Section 8.1.4.3.4 $\mathrm{in}^{24}$ ). These general default factors may, therefore, underestimate the magnitude of $\mathrm{CH}_{4}$ and $\mathrm{N}_{2} \mathrm{O}$ fluxes in other seagrass systems.

We observed considerable variability in $\mathrm{CH}_{4}$ and $\mathrm{N}_{2} \mathrm{O}$ fluxes at seagrass sites, especially during spring and summer months. More work is needed to understand site-specific drivers of $\mathrm{CH}_{4}$ and $\mathrm{N}_{2} \mathrm{O}$ production to better constrain annual fluxes ${ }^{48}$. This includes determining whether $\mathrm{CH}_{4}$ production varies with sediment $\mathrm{C}_{\text {org }}$ concentrations, whether $\mathrm{CH}_{4}$ and $\mathrm{CO}_{2}$ interactions affect $\mathrm{CH}_{4}$ release, and whether microbial community differences affect $\mathrm{CH}_{4}$ and $\mathrm{N}_{2} \mathrm{O}$ enhancement. We also note that using benthic chambers may have moderated release rates for both trace gases by inhibiting flow-induced efflux and that using experimentally cleared control sites, rather than bare sites outside the meadow, may have reduced the apparent seagrass enhancement effect. We advise other seagrass blue carbon studies to measure both trace gases directly, until a sufficient number of additional studies suggest conservative release rates for seagrass GHG accounting that are generally applicable.

Identifying the net GHG benefit from seagrass restoration. Studies based on burial rates have suggested that seagrass meadows may sequester more carbon in soils than terrestrial forests ${ }^{55}$. The net sequestration rate based on sediment and plant stock changes and emissions of $\mathrm{CH}_{4}$ and $\mathrm{N}_{2} \mathrm{O}$ that we measured in this study, $0.42 \mathrm{t} \mathrm{C} \mathrm{ha}^{-1} \mathrm{yr}^{-1}$, is lower than the average rates for temperate and tropical forests, 2.6 and $5.3 \mathrm{t} \mathrm{C} \mathrm{ha}^{-1} \mathrm{yr}^{-1}$, respectively $\mathrm{y}^{51}$, but generally agrees with the IPCC sequestration rate for seagrass systems, $0.43 \mathrm{tC} \mathrm{ha}^{-1} \mathrm{yr}^{-151}$. 


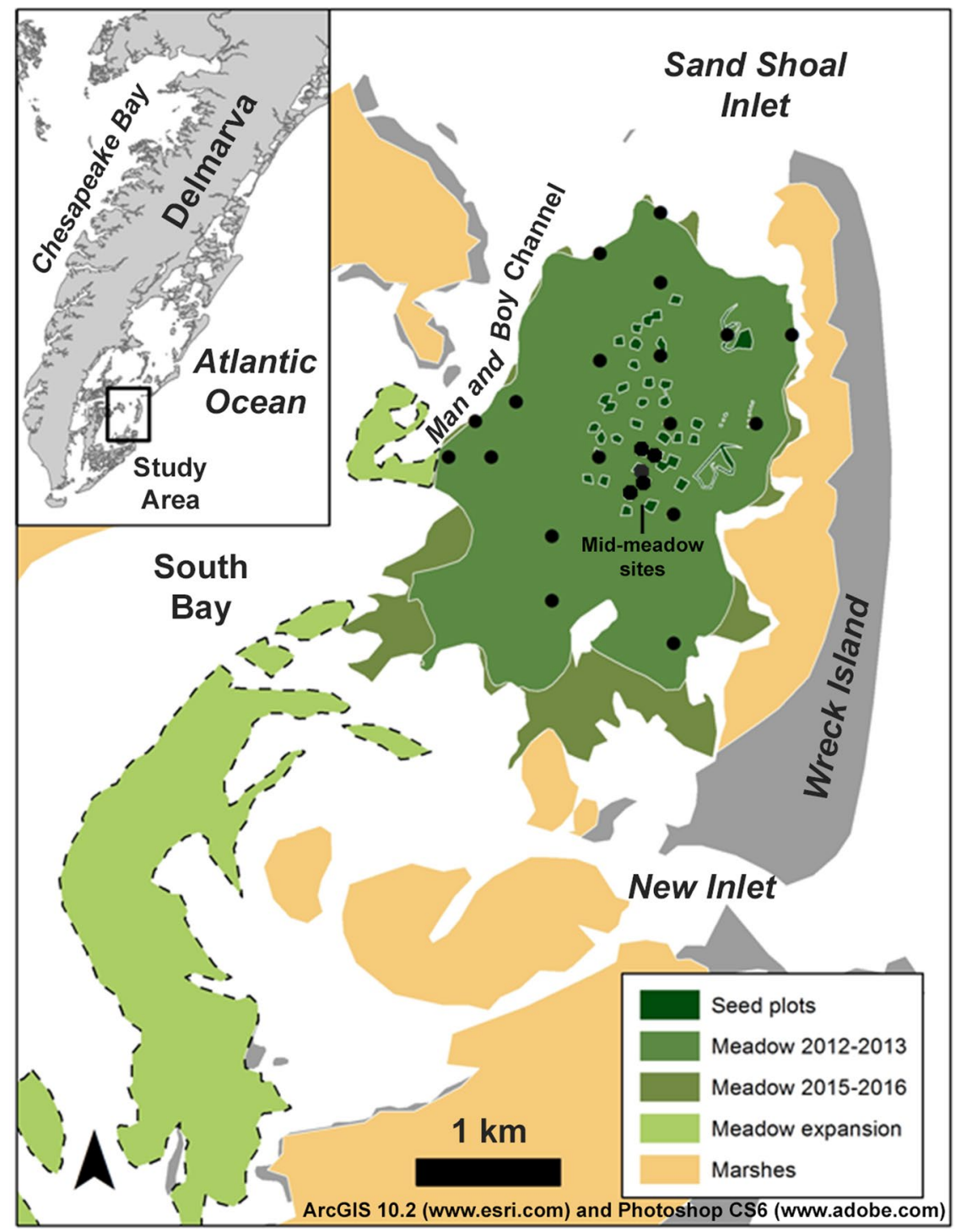

Figure 2. The South Bay, Virginia, study area, showing the locations of biomass and sediment $\mathrm{C}_{\text {org }}$ sample sites (black circles), original restoration seed plots (established in 2000-2001: Orth et al. ${ }^{70}$, the central meadow extent prior to sampling in 2013, and the expanded meadow extent prior to sampling in 2016. Meadow expansion areas to the west and south (light green areas enclosed by dashed lines) were excluded from the net GHG benefit calculations in this study. The figure was created in ArcGIS 10.2 (www.esri.com) and Photoshop CS6 (www. adobe.com).

Similar studies in other systems may also support the use of this default factor, but we note several reasons why this default factor may not be an appropriate rate for all seagrass systems at all times. First, the IPCC rate is double the sequestration rate that we calculated for the first decade of our restoration, $0.21 \mathrm{t} \mathrm{C} \mathrm{ha-1} \mathrm{yr}^{-1}$. Long-term research in this restored meadow has shown that it took about a decade for sediment carbon sequestration rates and plant biomass to be equivalent to natural meadows ${ }^{12}$. Second, sediment accretion may vary throughout the meadow. We assumed uniform sediment accretion, but actual accretion may be lower near the meadow edge, as evidenced by the grain size distribution and reported Reynolds stresses ${ }^{56,57}$ (see the Supplement). Third, our system has negligible carbonate, because the sediment in the region is siliciclastic, and there are no nearby coral reefs. We did not expect to find a significant difference in $\mathrm{CaCO}_{3}$ at seagrass and bare sites. This is not the case in other seagrass systems, where increased $\mathrm{CO}_{2}$ evasion may be significant (see the comparison between this system and others in Sadrene et al..$^{22}$ ). Finally, the South Bay meadow also appears to be metabolically balanced on a decadal time scale, but studies in autotrophic systems may need to determine whether direct plant metabolism increases $p \mathrm{CO}_{2}$ and results in a $\mathrm{CO}_{2}$ flux back to the atmosphere ${ }^{58,59}$. These caveats point to areas where future research needs to be done to verify how generally the IPCC default factor applies to seagrass ecosystems worldwide.

The stock change approach indicates that the carbon sequestration rate for this meadow is increasing but that net $\mathrm{CO}_{2}$ sequestration as a percentage of meadow-wide community GPP may be declining with meadow age. 


\begin{tabular}{|l|l|l|l|l|l|}
\hline & $\begin{array}{l}\text { 2001 Start } \\
\text { (Bare) }\end{array}$ & 2013 Gross & 2013 Net & 2016 Gross & 2016 Net \\
\hline Meadow area $\left(\mathrm{km}^{2}\right)$ & 0.096 & 5.79 & 5.79 & 6.86 & 6.86 \\
\hline $\mathrm{AGB}$ & 0 & $-710 \pm 14.8$ & $-710 \pm 14.8$ & $-810 \pm 17.6$ & $-810 \pm 17.6$ \\
\hline Live BGB & 0 & $-339 \pm 30.0$ & $-339 \pm 30.0$ & $-401 \pm 33.2$ & $-401 \pm 33.2$ \\
\hline Dead BGB & 0 & $-857 \pm 44.3$ & $-857 \pm 44.3$ & $-1020 \pm 52.5$ & $-1020 \pm 52.5$ \\
\hline Sediment $\mathrm{C}_{\text {org }}$ & $-78 \pm 6.29^{\mathrm{a}}$ & $-13500 \pm 792$ & $-4150 \pm 412$ & $-20400 \pm 3440$ & $-7360 \pm 1790$ \\
\hline Total GHG Benefit & & & -6060 & & -9590 \\
\hline $\mathrm{CH}_{4}$ & $0.5 \pm 0.20$ & $385 \pm 177$ & $335 \pm 156$ & $611 \pm 275$ & $532 \pm 249$ \\
\hline $\mathrm{N}_{2} \mathrm{O}$ & $1.5 \pm 0.64$ & $420 \pm 152$ & $264 \pm 84.6$ & $667 \pm 243$ & $420 \pm 134$ \\
\hline $\mathrm{CO}_{2}$ from CaCO & $3.8 \pm 1.14$ & $450 \pm 137^{\mathrm{b}}$ & $0^{\mathrm{c}}$ & $623 \pm 190^{\mathrm{c}}$ & $0^{\mathrm{c}}$ \\
\hline Total Emissions & 5.7 & 1260 & 599 & 1780 & 952 \\
\hline Net GHG benefit & & & -5460 & & -8630 \\
\hline
\end{tabular}

Table 3. Sequestered $\mathrm{CO}_{2}$ stocks (negative values), cumulative GHG emissions, and the net GHG benefit from the South Bay meadow in 2013 and in 2016; all values are $\mathrm{Mt} \mathrm{CO}_{2}$ equivalent units. Gross values = observed seagrass meadow-scale stocks; net values = seagrass meadow stock enhancement above the baseline (gross seagrass stocks - equivalent area bare stocks; aboveground biomass - AGB, belowground biomass - BGB); standard errors reflect error propagation. ${ }^{\mathrm{a} b a c k g r o u n d}$ (i.e. baseline) stock within total seed plot area. ${ }^{\mathrm{b}} \mathrm{The}_{\mathrm{CO}}$ and $\mathrm{CaCO}_{3}$ gas exchange/reaction ratio may vary; we used 0.6 , as discussed in the methods ${ }^{26}$. ${ }^{c}$ Note that we did not observe seagrass-enhanced $\mathrm{CaCO}_{3}$ burial in this system.
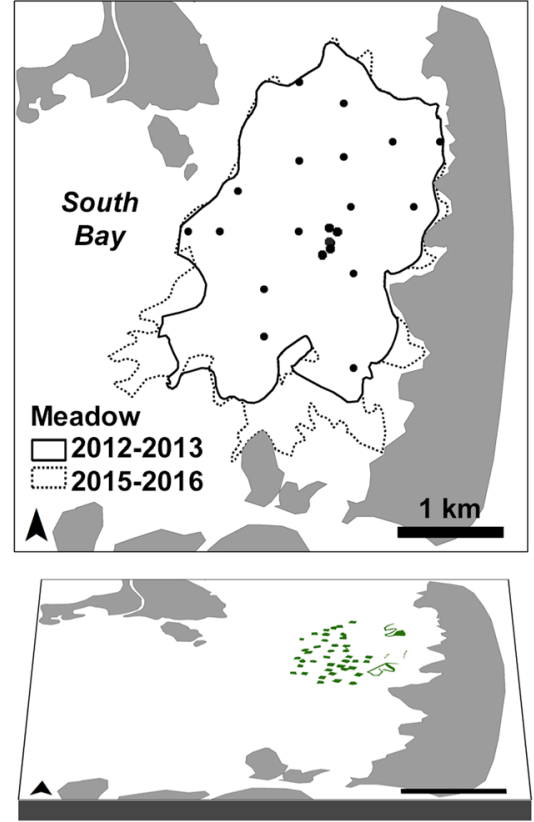

Seed plots ca. 2001 (Bare)

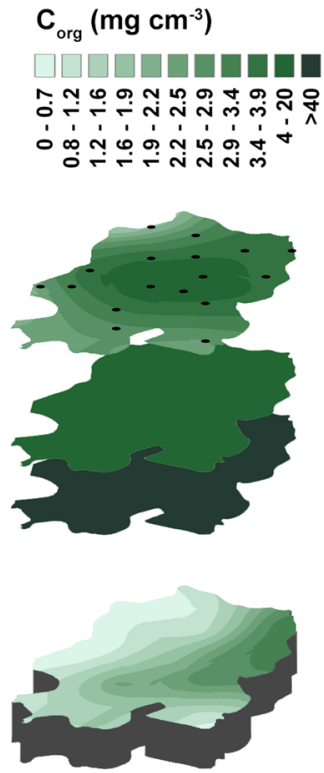

2013 Meadow

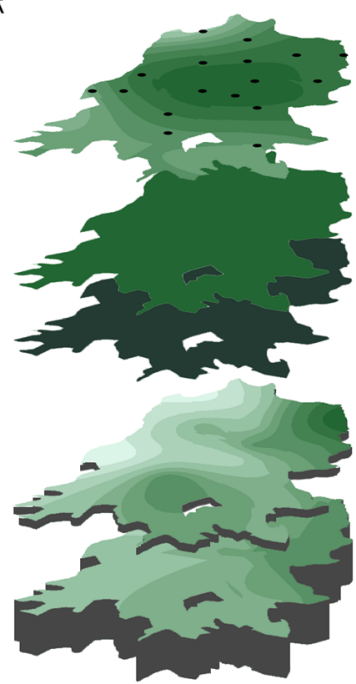

2016 Meadow
AGB

BGB

(live)

BGB

(dead)

SOC (accretion 2013-16)

SOC

$(12 \mathrm{~cm}$ avg.)

ArcGIS 10.2 (www.esri.com) (www.adobe.com)

Figure 3. Sequestered GHG pools (aboveground biomass - AGB, belowground biomass - BGB, and net sediment $C_{\text {org }}$ - SOC) in 2013 and in 2016 resulting from seagrass restoration; maps generated by kriging data measured at sample sites $(n=21$ : circles in inset map); note that the bed volume has changed over time due to both meadow expansion and accretion (see Supplement). The mid-meadow SOC decline in the 2016 accreted interval reflects a local seagrass die-off event in 2015. The figure was created in ArcGIS 10.2 (www.esri.com) and Photoshop CS6 (www.adobe.com).

Cumulative GPP increased by 114\% between 2013 and 2016, due largely to meadow expansion, but the enhanced sequestered stock only increased by $78 \%$ over this period. The fraction of GPP that is sequestered may increase over time if the meadow stops expanding and GPP reaches a long-term steady state. Recent work at this site has shown that GPP initially exceeded respiration in this meadow but later reached equivalence ${ }^{59,60}$, a finding that may pertain to eelgrass systems generally ${ }^{61}$. Studies need to determine whether carbon sequestration as a percentage of GPP changes over time in other systems, including those that appear to be net autotrophic ${ }^{30}$, and whether seagrass offset benefits continue to accumulate indefinitely. 
A

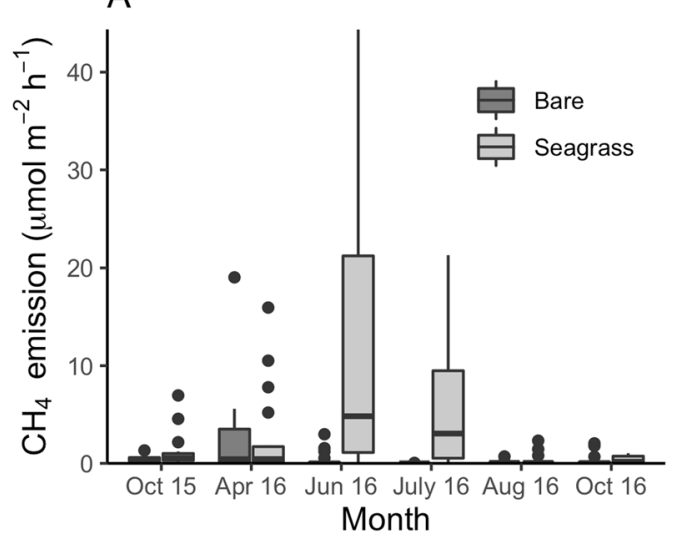

B

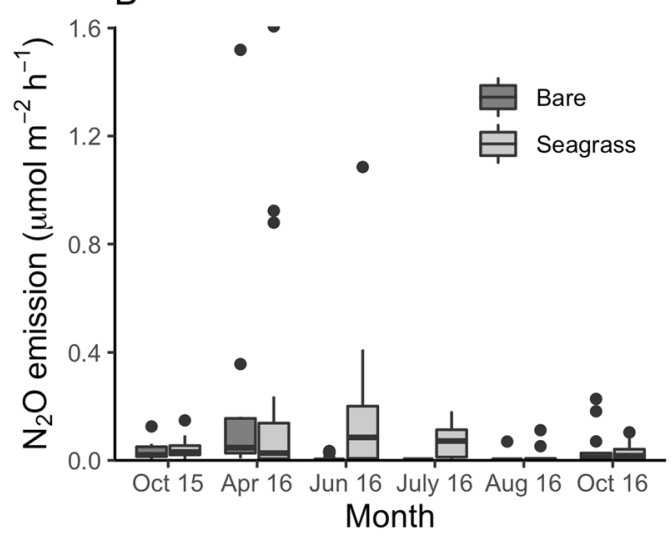

Figure 4. $\mathrm{CH}_{4}(\mathbf{A})$ and $\mathrm{N}_{2} \mathrm{O}(\mathbf{B})$ ebullition flux $\left(\mu \mathrm{mol} \mathrm{m} \mathrm{m}^{-2} \mathrm{hr}^{-1}\right)$ box plots (quartiles) at sites $(\mathrm{n}=10)$ by observation month (Oct. 2015-Oct. 2016) and by treatment (bare and seagrass). See Table 4 for log-likelihood ratio test results for assessing the treatment effect.

\begin{tabular}{|l|l|l|l|l|l|l|}
\hline & $\mathbf{D f}^{\mathbf{a}}$ & logLik & deviance & $\chi^{\mathbf{2}}$ & $\mathbf{D f}^{\mathbf{b}}$ & $\operatorname{Pr}\left(>\mathbf{\chi}^{2}\right)$ \\
\hline $\mathrm{CH}_{4} \wedge(0.133) \sim 1+(1 \mid \mathrm{ID})$ & 3 & -9.25 & 18.50 & & & \\
\hline $\mathrm{CH}_{4} \wedge(0.133) \sim$ Treat $+(1 \mid \mathrm{ID})$ & 4 & -2.71 & 5.41 & 13.08 & 1 & $2.98 \mathrm{E}-04$ \\
\hline $\begin{array}{l}\mathrm{CH}_{4} \wedge(0.133) \sim \text { Treat }+ \\
\text { Treat*Month }+(1 \mid \mathrm{ID})\end{array}$ & 14 & 15.51 & -31.02 & 36.44 & 10 & $7.08 \mathrm{E}-05$ \\
\hline $\mathrm{N}_{2} \mathrm{O}^{\wedge}(0.133) \sim 1+(1 \mid \mathrm{ID})$ & 3 & 9.70 & -19.39 & & & \\
\hline $\mathrm{N}_{2} \mathrm{O}^{\wedge}(0.133) \sim$ Treat $+(1 \mid \mathrm{ID})$ & 4 & 13.92 & -27.84 & 8.45 & 1 & $3.65 \mathrm{E}-03$ \\
\hline $\begin{array}{l}\mathrm{N}_{2} \mathrm{O}^{\wedge}(0.133) \sim \text { Treat }+ \\
\text { Treat }\end{array}$ & 14 & 31.83 & -63.65 & 35.81 & 10 & $9.09 \mathrm{E}-05$ \\
\hline
\end{tabular}

Table 4. Log-likelihood ratio test results for assessing a seagrass treatment effect (presence/absence) and a treatment*month interaction effect on benthic $\mathrm{CH}_{4}$ and $\mathrm{N}_{2} \mathrm{O}$ fluxes; rows relate the null model, reduced model, and full model for $\mathrm{CH}_{4}$ and $\mathrm{N}_{2} \mathrm{O}$, respectively. ${ }^{\mathrm{a}}$ Mixed effects model degrees of freedom determined by lmer function (see Bates et al ${ }^{78}$ ) b Likelihood ratio test degrees of freedom (the difference between models used in each comparison).

Given that measuring sediment $\mathrm{C}_{\text {org }}$ stock changes in a seagrass system is feasible, we recommend using this method to calculate seagrass net GHG benefits to avoid issues associated with using burial fluxes for this purpose $^{18}$. Use of ${ }^{210} \mathrm{~Pb}$ dating to calculate sedimentation rates in seagrass systems has been criticized where relatively short (decadal) time scales are addressed and where bioturbation could disturb sediment profiles ${ }^{18}$. A recent study used surface elevation tables (SET) to compare changes in surface elevation between bare and seagrass sites over short $(<1 \mathrm{yr})$ time scales ${ }^{62}$, but the SETs and marker horizons used widely in salt marshes are generally problematic in seagrass meadows. Subtidal currents re-suspend surface sediments, scouring occurs around vertical objects, including SET pins, and the high-water content of surface sediment makes precise (mm-scale) measurements of surface elevation difficult ${ }^{63}$. Burial rate sequestration estimates also assume that surface deposition is the primary vector for transferring $\mathrm{C}_{\text {org }}$ to the sediment, but we observed considerable $\mathrm{C}_{\text {org }}$ accumulation within the bed. This may be due to sediment $\mathrm{C}_{\text {org }}$ accumulation from root $\mathrm{C}_{\text {org }}$ exudates or from increased preservation of benthic microalgae migrating up and down within the sediment ${ }^{64}$. The sediment $\mathrm{C}_{\text {org }}$ stock increase that we observed, $874 \mathrm{tC}_{\text {org }}$, exceeded the increase we would have estimated by scaling the Greiner et al..$^{12}$ surface burial flux reported for this system by meadow area and by the three-year time period, $755 \mathrm{t} \mathrm{C}_{\text {org }}$. However, we also observed sediment $\mathrm{C}_{\text {org }}$ declines in 2016 at particular sites, which affected the 2016 sediment $\mathrm{C}_{\text {org }}$ spatial distribution (Fig. 3). Random disturbance events will likely affect long-term (i.e. decadal) sediment $\mathrm{C}_{\text {org }}$ accumulation rates by periodically removing sequestered sediment $\mathrm{C}_{\text {org }}$ stocks. A stock change approach captures these changes. Burial flux rates derived from dated sediment cores may need to be reconsidered, given the magnitude of the within bed $\mathrm{C}_{\text {org }}$ accumulation that we observed.

Individual seagrass projects should also take care to avoid overestimating the GHG offset benefit by failing to account for allochthonous $\mathrm{C}_{\text {org }}$. The VCS carbon-offset protocol conservatively requires that carbon fixed outside the project area (allochthonous carbon) be excluded from the GHG offset benefit, because this cannot be unequivocally attributed to the seagrass restoration project ${ }^{18,24}$. We conservatively deducted the background $\mathrm{C}_{\text {org }}$ concentration from the entire seagrass $\mathrm{C}_{\text {org }}$ profile to account for possible deposition of allochthonous carbon (see Fig. 1 and the Supplement). Including all of the sediment $\mathrm{C}_{\text {org }}$ in the accreted part of the South Bay bed would have almost doubled the apparent project benefit to $10.1 \mathrm{~K} \mathrm{tCO}_{2} \mathrm{e}$ in 2013 and $17.2 \mathrm{~K} \mathrm{t} \mathrm{CO}_{2} \mathrm{e}$ in 2016 . 


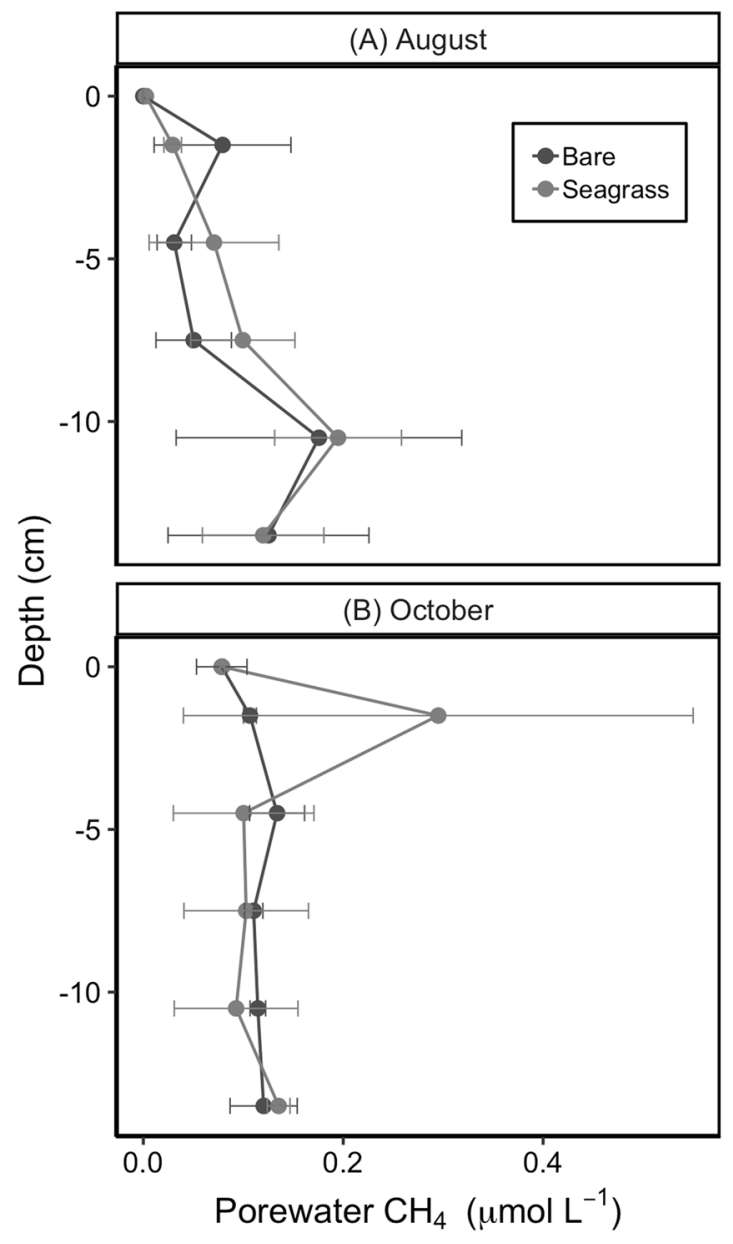

Figure 5. Porewater profile $\mathrm{CH}_{4}$ concentrations measured at bare and seagrass sites in August $(\mathbf{A}$ : $\operatorname{site} \mathrm{n}=6$ ) and in October $2016(\mathbf{B}$ : site $\mathrm{n}=4)$.

Offset-credit finance as an incentive for seagrass restoration. Had this restoration project been able to apply for VCS offset-credits in 2001, it would now receive up to 8,630 credits. The actual allocation of credits would be slightly lower to account for $\mathrm{CO}_{2}$ emissions from project activities (i.e. travel to restoration sites, etc.) and 'buffer pool' set aside credits to account for the risk of GHG offset gain reversals ${ }^{24}$. Investors do not typically consider GHG offset projects viable unless they sequester at least $50,000 \mathrm{tCO}_{2}$ e over the project lifetime (typically 30 years ${ }^{65}$. Reaching 50,000 credits by 2031 would require a further increase in the $\mathrm{C}$ sequestration rate by this meadow. Future work, including repeated carbon stock change measurements and bed accretion measurements, will be necessary to determine whether the sequestration rate continues to increase.

Given current market prices, carbon offset-credits currently provide a marginal incentive for seagrass restoration. At a price of $\$ 10$ ton $^{-1}$, offset-credits would finance approximately $10 \%$ of the approximately $\$ 800 \mathrm{~K}$ South Bay restoration $\operatorname{cost}^{17,66}$. Fully financing a seagrass restoration project with a unit cost equivalent to this South Bay Z. marina restoration would require a voluntary offset price greater than $\$ 95$ per $\mathrm{MtCO}_{2}$ e. This cost-benefit comparison excludes project development costs, which may exceed $\$ 100 \mathrm{~K}$, and net present value discounting. We note that the carbon burial rates measured in South Bay are on the low end of those documented for other seagrass meadows globally ${ }^{5}$. Other species and locations may generate larger sediment $\mathrm{C}_{\text {org }}$ stocks than we measured for Z. marina over time (e.g. ${ }^{67)}$. However, the South Bay restoration was accomplished at a unit cost of only $\$ 1,200 \mathrm{ha}^{-117}$, and the range for other seagrass projects is $\$ 1,900-4,000,000 \mathrm{ha}^{-154}$.

Rather than rely solely on carbon offset-credits to finance meadow restoration, coastal managers should think holistically about the other values that seagrass systems provide, including fisheries support, nutrient removal, and reduced marsh erosion, among other services. Quantifying these values, even absent markets for co-benefit 'credits,' would provide further incentive for seagrass restoration, in addition to carbon sequestration.

\section{Methods}

Study area. We measured all of the parameters required by the VCS methodology to quantify the GHG offset benefit from the $Z$. marina restoration in South Bay, $\mathrm{VA}^{24}$. The restoration history ${ }^{68}$, project $\operatorname{cost}{ }^{17}$, sediment $\mathrm{C}_{\text {org }}$ stock enhancement ${ }^{12,57,69}$, and net ecosystem metabolism ${ }^{58-60}$ of this meadow have been documented and provide a baseline for stock-change assessment. The South Bay meadow area is shallow, with an average depth at mean sea level of $0.76 \pm 0.28$ (SD) $\mathrm{m}$, and oligotrophic, with low nutrient loading (Fig. 2) (57 $^{57}$ For additional background on 


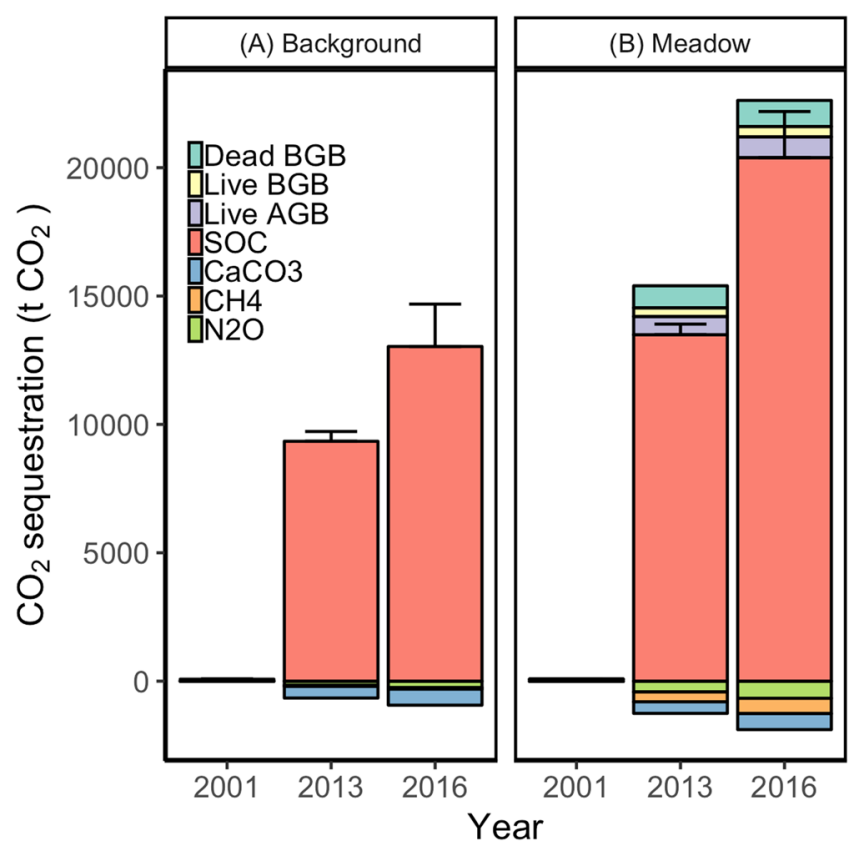

Figure 6. Cumulative background (A) and gross meadow (B) GHG stocks in the meadow areas over time; sequestration (i.e., GHG uptake from the atmosphere) in this figure is shown as positive, $\mathrm{GHG}$ release (i.e., a GHG flux to the atmosphere) is negative; $\mathrm{CH}_{4}$ and $\mathrm{N}_{2} \mathrm{O}$ quantities were standardized to $\mathrm{CO}_{2} \mathrm{e}$; ' $\mathrm{CaCO}_{3}$ ' relates $\mathrm{CO}_{2}$ evasion attributable to $\mathrm{CaCO}_{3}$; background stocks were calculated by scaling average bare site values by total meadow area at each time step; net stock enhancement attributable to the meadow (see Table 3) can be calculated by subtracting the bare values (A) from equivalent gross meadow values (B); Error bars represent $\mathrm{SE}$ for the sediment $\mathrm{C}_{\text {org }}(\mathrm{SOC})$ stock.

the Virginia Coast Reserve Long-Term Ecological Research eelgrass restoration, including reseeding methods, see Orth and McGlathery ${ }^{68}$ and other studies in the Marine Ecology Progress Series v. $448^{69,70}$.

Sediment $\mathrm{C}_{\text {org }}$ stock enhancement. Meadow sediment $\mathrm{C}_{\text {org }}$ stock enhancement was determined for both 2013 and 2016 by subtracting baseline sediment (i.e., bare) $C_{\text {org }}$ stocks from the gross stocks measured within the meadow (Fig. 1). $\mathrm{C}_{\text {org }}$ is generally present in subtidal sediment without seagrass meadows, and this background $\mathrm{C}_{\text {org }}$ should not be attributed to a seagrass restoration project. The restored meadow was already in existence when we began sampling in 2013, so time $=0$ values at sites within the meadow were not available. The sediment $C_{\text {org }}$ baseline scenario (the Emmer et al. ${ }^{24}$ 'without project' scenario) that would represent pre-restoration (time $=0$ ) was, therefore, established by measuring $\mathrm{C}_{\text {org }}$ concentrations at bare control sites outside the meadow. The average $\mathrm{C}_{\text {org }}$ concentration in cores collected at four bare sites by Greiner et al. ${ }^{12}$ in 2011 and by Oreska et al. ${ }^{57,64}$ in 2013 and in 2014 was $3.67 \pm 0.55$ (SE) $\mathrm{mg} \mathrm{C}_{\text {org }} \mathrm{cm}^{-3}$ (see Supplement). We verified that this background concentration remained unchanged by collecting new, replicate cores $(n=4)$ at two of these bare sites in 2016 . We deducted this average background sediment $\mathrm{C}_{\text {org }}$ concentration from the sediment $\mathrm{C}_{\text {org }}$ concentrations measured within the meadow in 2013 and in 2016 to identify the $C_{\text {org }}$ attributable to the seagrass restoration (Fig. 1). This is in accordance with the stock change assessment recommended by the VCS methodology ${ }^{24}$.

We assessed $\mathrm{C}_{\text {org }}$ changes at sites within the meadow in 2016 by resampling 16 randomly-selected meadow sites first sampled by Oreska et al. ${ }^{57}$ in 2013 (the 'with project' scenario). Four $12-\mathrm{cm}$ long, $2.7 \mathrm{~cm}$ diameter cores were collected at each site and subdivided into $3-\mathrm{cm}$ intervals. Macroscopic roots and rhizomes were removed from each sample manually, using tweezers. Note that belowground biomass (BGB) was quantified separately, as described in the following section, to avoid double counting. All sediment samples were prepared according to methods used previously in this system ${ }^{12,57,64}$. We measured \%C on a Thermo Scientific Flash 2000 Organic Element Analyzer; $\% \mathrm{C}_{\text {org }}$ was determined by subtracting $\% \mathrm{C}_{\text {inorg }}$, which we determined using element analysis of samples ashed at $500^{\circ} \mathrm{C}$ for six hours ${ }^{71}$. The element analyzer average percent error was $0.48 \%$, based on analysis of lab standards.

Allochthonous $\mathrm{C}_{\text {org }}$ may be deposited within the bed due to bed accretion (Fig. 1). Rather than deduct an arbitrary 'allochthonous compensation factor' from the meadow sediment $\mathrm{C}_{\text {org }}$ stock ${ }^{72,73}$, we accounted for allochthonous $\mathrm{C}_{\text {org }}$ that could have been deposited in the baseline scenario by deducting the bare site sediment $\mathrm{C}_{\text {org }}$ average from the entire meadow carbon profile, including the part of the sediment profile that may have resulted from accretion facilitated by the meadow (see Fig. 1 and the Supplement for more explanation).

Total, meadow-enhanced sediment $\mathrm{C}_{\text {org }}$ stocks in 2013 and in 2016 were quantified by interpolating the average 2013 and 2016 sediment $C_{\text {org }}$ enhancement at each site in ArcGIS 10.2 Geostatistical Analyst using Ordinary Kriging $^{74}$. We fitted stable, circular, spherical, Guassian, and exponential semivariogram models to each dataset and selected the sediment $\mathrm{C}_{\text {org }}$ distribution maps with the lowest root mean square errors (Supplement). The 2013 
data was best fit using a circular model, the equivalent 2016 data was best fit using a Gaussian model, and the uppermost 2-cm interval in 2016, which may be the result of accretion and is shown separately in Fig. 3, was best fit using an exponential model.

Biomass $\mathrm{CO}_{2}$ sequestration. The carbon sequestered in seagrass tissue is periodically lost to export, herbivory, and decomposition, so we calculated and reported the average, annual standing biomass stock based on seasonal measurements from 2014-2016 (see Supplement). This represents a running average that reflects periodic export and other fluctuations, rather than peak observed biomass. This is the same general approach that reforestation GHG offset projects use to address the cyclical harvest and replanting of aboveground biomass (AGB), and it is permitted for seagrass GHG accounting ${ }^{24}$. Shoot densities ranged from approximately 250 to 617 shoots $\mathrm{m}^{-2}$ in South Bay due to seasonal thinning and export, and biomass ranged from 0.26 to $0.781 \mathrm{gdw}$ shoot $^{-1}$. We accounted for variability in AGB using existing density measurements (shoots $\mathrm{m}^{-2}$ ) taken at sites throughout this meadow over time to account for seasonal changes ${ }^{57,75}$. The average density over the course of a year was approximately half of the peak density observed during July $(48 \%)^{57,75}$

We quantified average AGB per shoot and BGB by collecting additional replicate $(\mathrm{n} \geq 4) 15.2$-cm diameter biomass cores seasonally from June 2014 to June 2016 to a depth of $15 \mathrm{~cm}$ at five central meadow sites (see Supplement), following methods employed by past studies in this system ${ }^{69,76}$. We also collected biomass cores $(n \geq 3)$ at four additional, systematically located sites during the summer of 2016 (see Supplement). Samples were sieved using a 1-mm mesh, separated the same day into live and dead fractions, and then dried to a constant weight at $60^{\circ} \mathrm{C}$. Biomass data-both live and dead-was averaged by site and then by month to generate seasonal averages, which were used to calculate the average, annual standing stocks. The average, annual shoot densities were multiplied by the average biomass shoot ${ }^{-1}, 0.41 \pm 0.09 \mathrm{gdw} \operatorname{shoot}^{-1}$ (this study), and by $37.1 \% \mathrm{C} \mathrm{gdw}^{-1}$ biomass $^{76}$. The resulting aboveground biomass values $\left(\mathrm{C}_{\text {org }} \mathrm{m}^{-2}\right)$ were interpolated using Ordinary Kriging in ArcGIS 10.2 Geostatistical Analyst and a Gaussian semivariogram to generate average, annual AGB stocks for the 2013 and 2016 meadow extents. Average live and dead BGB values $\left(\mathrm{g} \mathrm{m}^{-2}\right)$ were multiplied by the average $\mathrm{C}_{\text {org }}$ fraction in belowground biomass, $33.8 \% \mathrm{C}_{\mathrm{org}} \mathrm{gdw}^{-1}$ biomass $^{77}$, and scaled by the 2013 and 2016 meadow areas to generate $\mathrm{C}_{\text {org }}$ stocks.

GHG fluxes. We deployed clear plastic, bell-shaped benthic chambers over vegetated and experimentally cleared $2 \mathrm{~m} \times 2 \mathrm{~m}$ bare plots at the five central meadow sites to identify changes in benthic $\mathrm{CH}_{4}$ and $\mathrm{N}_{2} \mathrm{O}$ fluxes attributable to $Z$. marina presence. Each chamber sat on the sediment surface, covering a $0.046 \mathrm{~m}^{2}$ circular area and enclosing a $10.5 \mathrm{~L}$ volume. Comparing fluxes at cleared, central meadow plots allowed us to control for confounding factors at bare sites outside of the meadow. These areas are generally deeper with more sand-sized sediment and experience greater Reynolds stresses, because of area geomorphology ${ }^{56}$, factors that may affect sediment:water gas exchange. We cleared the bare plots during spring 2015, installed plastic lawn edging to a depth of $8 \mathrm{~cm}$ to prevent seagrass rhizome re-colonization, and allowed plots to equilibrate for five months. Comparing seagrass and cleared bare plots to assess a seagrass enhancement effect on $\mathrm{CH}_{4}$ and $\mathrm{N}_{2} \mathrm{O}$ was conservative, because some seagrass BGB potentially remained at the cleared plots and may have contributed to microbial production of these trace gases. Eight chambers were deployed at each site during each observation, four replicates over seagrass and four over bare sediment. Every deployment exactly bracketed low tide, such that gas accumulation time captured equal parts falling- and rising-tide. Deployment durations ranged from 1 to 5 hours. Trace gases were collected on multiple days per month in October 2015, April 2016, June 2016, July 2016, August 2016, and October 2016. Using chambers allowed us to conduct a controlled experiment in situ to test for a seagrass presence effect, but we acknowledged that using benthic chambers may have introduced container effects that affected release rates, including the elimination of hydrodynamic flow-induced efflux.

The gas that collected in each chamber was syringe extracted and injected into an exetainer filled with $12 \mathrm{ml}$ $\mathrm{N}_{2}$ and $0.2 \mathrm{ml} 0.01 \mathrm{M} \mathrm{ZnC}_{4} \mathrm{H}_{6} \mathrm{O}_{4}$ to prevent microbial activity resulting from the syringe transfer. The total gas volume collected within each chamber was noted and used to calculate the gas flux as a function of time and bed surface area. We also measured bulk $\mathrm{CH}_{4}$ concentrations in replicate porewater samples collected at bare and vegetated sites in August (site $n=6$ ) and October ( relative to the ebullition flux. We extracted $7 \mathrm{ml}$ of porewater through mini-piezometers (inner diameter $1.8 \mathrm{~mm}$ ) at $3-\mathrm{cm}$ intervals, from $1.5 \mathrm{~cm}$ down to $13.5 \mathrm{~cm}$. The water samples were syringe injected into exetainers filled with $12 \mathrm{ml} \mathrm{N}_{2}$ and fixed with $0.2 \mathrm{ml} \mathrm{ZnCl}_{2}$. The diffusive flux was calculated using Fick's first law of diffusion:

$$
\text { Flux }=-\mathrm{DsdC} / \mathrm{dx}
$$

where the sediment diffusivity, Ds, was assumed to be $0.1 \times 10^{-4} \mathrm{~cm}^{2} \mathrm{~s}^{-1}$.

All exetainer samples were analyzed on a Varian 450-Gas Chromatograph with a Bruker GC/MS workstation at the Smithsonian Environmental Research Center. We determined sample $\mathrm{CH}_{4}$ and $\mathrm{N}_{2} \mathrm{O}$ concentrations using onsite standards and corrected for differences in atmospheric temperature and pressure during each GC analysis. Standard curve $\mathrm{R}^{2}$ values ranged from 0.992 to 0.996 .

We tested for an effect of seagrass presence on $\mathrm{CH}_{4}$ and $\mathrm{N}_{2} \mathrm{O}$ fluxes using linear mixed effect models in $\mathrm{R}^{78,79}$. Replicate results were averaged by site. Seagrass presence/absence and month were treated as fixed effects; individual sites were randomly selected. Tests were run on each GHG dataset using the lmer function (lme4 package version 1.1-14). We expected to find increased GHG fluxes attributable to seagrass presence, as well as a seagrass*month interaction effect. Both the $\mathrm{CH}_{4}$ and $\mathrm{N}_{2} \mathrm{O}$ datasets required transformation due to heteroskedasticity and the presence of outliers. The optimal transformation (identified using the optim.boxcox function in the boxcoxmix package version 0.14) for the averaged data was $\lambda=0.133$ (Maximum log-likelihood $=-77.608$ ). Model $p$-values were obtained from likelihood ratio tests on the full model and a reduced model without the fixed effects. 
Average, annual seagrass and bare $\mathrm{CH}_{4}$ and $\mathrm{N}_{2} \mathrm{O}$ fluxes were determined by first averaging fluxes by season and then averaging the seasonal averages. Note that the early June observations were included as spring values and that we conservatively reported 9-month averages. The difference between seagrass and bare values represented the net fluxes attributable to seagrass presence. All statistics were calculated in $\mathrm{R}$ ( $\mathrm{R}$ stats package version 3.4.2) ${ }^{79}$.

$\mathrm{CO}_{2}$ evasion attributable to $\mathrm{C}_{\text {inorg }}$ was estimated by multiplying the $\mathrm{C}_{\text {inorg }}$ stock by a $\mathrm{CO}_{2}$ and $\mathrm{CaCO}_{3}$ gas exchange/reaction ratio of 0.6 , following Howard et al. ${ }^{26}$. We determined whether or not seagrass presence increased $\mathrm{C}_{\text {inorg }}$ concentrations by running a paired $t$-test on average, depth-calibrated $\mathrm{C}_{\text {inorg }}$ concentrations from $20-\mathrm{cm}$ cores collected at a representative meadow site and a representative bare site in this system.

Net GHG benefit accounting. Total meadow $\mathrm{CO}_{2}$ sequestration was calculated for both 2013 and 2016 by summing the above- and belowground biomass (both live and dead) and meadow-enhanced sediment $\mathrm{C}_{\text {org }}$ stocks measured in each year. Cumulative, enhanced $\mathrm{CH}_{4}$ and $\mathrm{N}_{2} \mathrm{O}$ emissions attributable to the meadow were estimated by multiplying the average enhanced (i.e., net) fluxes $\left(\mathrm{g} \mathrm{m}^{-2} \mathrm{yr}^{-1}\right)$ by meadow area over time. Meadow area changes were calculated in ArcGIS 10.2 by georeferencing the Virginia Institute of Marine Science aerial photographs for every year after initial reseeding in 2001 and delineating the meadow perimeter ${ }^{74,80}$. Meadow area was interpolated for the three years where photographs were unavailable. These cumulative, net GHG emissions calculated for 2013 and for 2016 were subtracted from the respective meadow-enhanced $\mathrm{CO}_{2}$ sequestration results to determine the net GHG benefit in each year (note that seagrass-enhanced $\mathrm{CO}_{2}$ emissions from $\mathrm{CaCO}_{3}$ were not observed).

We compared the total meadow sequestration in 2013 and in 2016 with the total, cumulative GPP within the meadow in each of those years to estimate the percentage of total GPP sequestered by the meadow. Cumulative GPP was estimated as a function of shoot density and meadow area. The relationship between meadow age and density was determined by fitting a polynomial regression to existing data from this meadow collected as part of the annual VCR-LTER seagrass survey ${ }^{81}$. This relationship was observed by Berger et al. ${ }^{59}$ to be:

$$
\mathrm{Y}=-0.678 \mathrm{x}^{3}+13.058 \mathrm{x}^{2}-9.42 \mathrm{x}
$$

where $\mathrm{Y}$ was shoot density in shoots $\mathrm{m}^{-2}$, and $\mathrm{x}$ was the meadow age in years $\left(\mathrm{R}^{2}=0.91\right)$. GPP was calculated using the following relationship observed in this meadow by Berger et al. ${ }^{59}$ :

$$
\mathrm{Y}=48.955+0.304 \mathrm{x}
$$

where $\mathrm{x}$ was density (shoots $\mathrm{m}^{-2}$ ) and $\mathrm{Y}$ was GPP in $\mathrm{mmol} \mathrm{O}_{2} \mathrm{~m}^{-2} \mathrm{~d}^{-1}\left(\mathrm{R}^{2}=0.69\right)$. Calculated GPP values for meadow areas of different age were summed and integrated over time to generate cumulative values.

\section{Data availability}

Data reported and analyzed in this study is available in the Supplement and on the LTER Network Data Portal (https://portal.lternet.edu/nis/home.jsp).

Received: 16 July 2019; Accepted: 6 April 2020;

Published online: 30 April 2020

\section{References}

1. Duarte, C. M., Middelburg, J. J. \& Caraco, N. Major role of marine vegetation on the oceanic carbon cycle. Biogeosciences 2, 1-8 (2005).

2. Champenois, W. \& Borges, A. V. Seasonal and interannual variations of community metabolism rates of a Posidonia oceanica seagrass meadow. Limnol. Oceanogr. 57(1), 347-361 (2012).

3. Tokoro, T. et al. Net uptake of atmospheric CO2 by coastal submerged aquatic vegetation. Glob. Chang. Biol. 20(6), 1873-1884 (2014).

4. Gullström, M. et al. Blue carbon storage in tropical seagrass meadows relates to carbonate stock dynamics, plant sediment processes, and landscape context: insights from the Western Indian Ocean. Ecosys. 21, 511-566 (2018).

5. Fourqurean, J. W. et al. Seagrass ecosystems as a globally significant carbon stock. Nat. Geosci. 5, 505-509 (2012).

6. Orth, R. J. et al. A global crisis for seagrass ecosystems. BioSci. 56(12), 987-996 (2006).

7. Waycott, M. et al. Accelerating loss of seagrass across the globe threatens coastal ecosystems. Proc. Natl. Acad. Sci. 106(30), 12377-12381 (2009).

8. Macreadie, P. I. et al. Losses and recovery of organic carbon from a seagrass ecosystem following disturbance. Proc. B. 282(1817), 20151537, https://doi.org/10.1098/rspb.2015.1537 (2015).

9. Marbà, N. et al. Impact of seagrass loss and subsequent revegetation on carbon sequestration and stocks. J. Ecol. 103, 296-302 (2015).

10. Lovelock, C. E. et al. Assessing the risk of carbon dioxide emissions from blue carbon ecosystems. Front. Ecol. Env. 15(5), 257-265 (2017).

11. Pendleton, L. et al. Estimating global "blue carbon" emissions from conversion and degradation of vegetated coastal ecosystems. PLoS ONE 7(9), e43542, https://doi.org/10.1371/journal.pone.0043542 (2012).

12. Greiner, J. T., McGlathery, K. J., Gunnell, J. \& McKee, B. A. Seagrass restoration enhances "blue carbon" sequestration in coastal waters. PLoS ONE 8(8), e72469, https://doi.org/10.1371/journal.pone.0072469 (2013).

13. Thorhaug, A., Poulos, H. M., López-Portillo, L., Ku, T. C. W. \& Berlyn, G. P. Seagrass blue carbon dynamics in the Gulf of Mexico: Stocks, losses from anthropogenic disturbance, and gains through seagrass restoration. Sci. Total Environ. 605-6, 626-636 (2017).

14. Nellemann, C., et al. Blue Carbon. A Rapid Response Assessment. United Nations Environment Programme 1-80 (GRID-Arendal (2009).

15. Röhr, M. E. et al. Blue carbon storage capacity of temperate eelgrass (Zostera marina) meadows. Global Biogeochem. Cycles 32(10), 1457-1475 (2018).

16. Russell, M. \& Greening, H. Estimating benefits in a recovering estuary: Tampa Bay, Florida. Estuaries Coast. 38(Suppl 1), S9-S18 (2015). 
17. Reynolds, L. K., Waycott, M., McGlathery, K. J. \& Orth, R. J. Ecosystem services returned through seagrass restoration. Restor. Ecol. 24(5), 583-588 (2016).

18. Johannessen, S. C. \& Macdonald, R. W. Geoengineering with seagrasses: is credit due where credit is given? Env. Res. Letters 11, 113001, https://doi.org/10.1088/1748-9326/11/11/113001 (2016).

19. Belshe, E. F., Mateo, M. A., Gillis, L., Zimmer, M. \& Teichberg, M. Muddy waters: unintentional consequences of blue carbon research obscure our understanding of organic carbon dynamics in seagrass ecosystems. Front. Mar. Sci. 4, 125, https://doi. org/10.3389/fmars.2017.00125 (2017).

20. Howard, J. L., Creed, J. C., Aguiar, M. V. P. \& Fourqurean, J. W. $\mathrm{CO}_{2}$ released by carbonate sediment production in some coastal areas may offset the benefits of seagrass "Blue Carbon" storage. Limnol. Oceanogr. 63(1), 160-172 (2018).

21. Macreadie, P. I., Serrano, O., Maher, D. T., Duarte, C. M. \& Beardall, J. Addressing calcium carbonate cycling in blue carbon accounting. Limnol. Oceanogr. Lett. 2, 195-201 (2017).

22. Saderne, V. et al. Role of carbonate burial in "blue carbon" budgets. Nat. Commun. 10, 1106, https://doi.org/10.1038/s41467-01908842-6 (2019).

23. Verified Carbon Standard. VCS Project Database. Available at: http://www.vcsprojectdatabase.org/ (2017).

24. Emmer, I., et al. Methodology for Tidal Wetland and Seagrass Restoration. Verified Carbon Standard, VM0033 Version 1.0. https:// verra.org/methodology/vm0033-methodology-for-tidal-wetland-and-seagrass-restoration-v1-0/ (2015).

25. Emmer I., von Unger, M., Needelman, B.A., Crooks, S., \& Emmett-Mattox, S. Coastal Blue Carbon in Practice: A Manual for Using the VCS Methodology for Tidal Wetland and Seagrass Restoration, V 1.0. 82p (Arlington, VA: Restore America"s Estuaries (2015).

26. Howard, J. et al. Clarifying the role of coastal and marine systems in climate mitigation. Front. Ecol. Environ. 15(1), 42-50 (2017).

27. Duarte, C. M. Reviews and syntheses: Hidden forests, the role of vegetated coastal habitats in the ocean carbon budget. Biogeosciences 14, 301-310 (2017)

28. Röhr, M. E., Boström, C., Canal-Vergés, P. \& Holmer, M. Blue carbon stocks in Baltic Sea eelgrass (Zostera marina) meadows. Biogeosciences 13, 6139-6153 (2016).

29. Rozaimi, M. et al. Carbon stores from a tropical seagrass meadow in the midst of anthropogenic disturbance. Mar. Poll. Bull. 119, 253-260 (2017)

30. Duarte, C. M. et al. Seagrass community metabolism: assessing the carbon sink capacity of seagrass meadows. Global Biogeochem. Cycles 24, GB4032, https://doi.org/10.1029/2010GB003793 (2010).

31. Johnson, R. A., Gulick, A. G., Bolten, A. B. \& Bjorndal, K. A. Blue carbon stores in tropical seagrass meadows maintained under green turtle grazing. Sci. Rep. 7, 13545, https://doi.org/10.1038/s41598-017-13142-4 (2017).

32. Oreska, M. P. J. et al. Comment on Geoengineering with seagrasses: is credit due where credit is given? Environ. Res. Lett. 13(3), 038001, https://doi.org/10.1088/1748-9326/aaae72 (2018).

33. Mateo, M. A., Cebrián, J., Dunton, K., \& Mutchler, T. Carbon flux in seagrass ecosystems in Seagrasses: Biology, Ecology and Conservation (eds. Larkum, A. W. D., Orth, R. J., \& Duarte, C. M.) 159-192 (Netherlands: Springer (2006).

34. Needelman, B. et al. The science and policy of the Verified Carbon Standard Methodology for Tidal Wetland and Seagrass Restoration. Estuaries Coast. 41(8), 2159-2171 (2018).

35. Neubauer, S. C. \& Megonigal, J. P. Moving beyond global warming potentials to quantify the climatic role of ecosystems. Ecosystems 18, 1000-1013 (2015)

36. United Nations Framework Convention on Climate Change (UNFCCC). Global Warming Potentials. http://unfccc.int/ghg_data/ items/3825.php (2017).

37. Roughan, B. L., Kellman, L., Smith, E. \& Chmura, G. L. Nitrous oxide emissions could reduce the blue carbon value of marshes on eutrophic estuaries. Environ. Res. Lett. 13, 044034, https://doi.org/10.1088/1748-9326/aab63c (2018).

38. Pollard, P. C. \& Moriarty, D. J. W. Organic carbon decomposition, primary and bacterial productivity, and sulphate reduction, in tropical seagrass beds of the Gulf of Carpentaria, Australia. Mar. Ecol. Prog. Ser. 69, 149-159 (1991).

39. Welsh, D. et al. Denitrification, nitrogen fixation, community primary productivity and inorganic-N and oxygen fluxes in an intertidal Zostera noltii meadow. Mar. Ecol. Prog. Ser. 208, 65-77 (2000).

40. Holmer, M., Anderson, F. Ø., Nielsen, S. L. \& Boschker, H. T. S. The importance of mineralization based on sulfate reduction for nutrient regeneration in tropical seagrass sediments. Aquat. Bot. 71, 1-17 (2001).

41. Poffenbarger, H. J., Needelman, B. A. \& Megonigal, J. P. Salinity influence on methane emissions from tidal marshes. Wetlands 31, 831-842 (2011).

42. Shieh, W. Y. \& Yang, J. T. Denitrification in the rhizosphere of the two seagrasses Thalassia hemprichii (Ehrenb.) Aschers and Halodule uninervis (Forsk.) Aschers. J. Exp. Mar. Biol. Ecol. 218, 229-241 (1997).

43. Oremland, R. S. Methane production in shallow-water, tropical marine sediments. Appl. Environ. Microbiol. 30(4), 602-608 (1975). 44. Moriarty, D. J. W. et al. Microbial biomass and productivity in seagrass beds. Geomicrobiology Journal 4(1), 21-51 (1985).

45. Isaksen, M. F. \& Finster, K. Sulphate reduction in the root zone of the seagrass Zostera noltii on the intertidal flats of a coastal lagoon (Arcachon, France). Mar. Ecol. Prog. Ser. 137, 187-194 (1996).

46. Lee, K.-S. \& Dunton, K. H. Diurnal changes in pore water sulfide concentrations in the seagrass Thalassia testudinum beds: the effects of seagrasses on sulfide dynamics. J. Exp. Mar. Bio. Ecol. 255, 201-214 (2000).

47. Rosentreter, J. A., Maher, D. T., Erler, D. V., Murray, R. H. \& Eyre, B. D. Methane emissions partially offset "blue carbon" burial in mangroves. Sci. Adv. 4, eaao4985, https://doi.org/10.1126/sciadv.aao4985 (2018).

48. Al-Haj, A. N., \& Fulweiler, R. W. A synthesis of methane emissions from shallow water coastal ecosystems. Global Change Biol. https://doi.org/10.1111/gcb.15046 (2020).

49. Garcias-Bonet, N. \& Duarte, C. M. Methane production by seagrass ecosystems in the Red Sea. Front. Mar. Sci. 4, 340, https://doi. org/10.3389/fmars.2017.00340 (2017).

50. Nakagawa, T., Tsuchiya, Y., Ueda, S., Fukui, M. \& Takahashi, R. Eelgrass sediment microbiome as a nitrous oxide sink in brackish Lake Akkeshi, Japan. Microbes Environ. 34(1), 13-22 (2019).

51. Intergovernmental Panel on Climate Change (IPCC). 2013 Supplement to the 2006 IPCC Guidelines for National Greenhouse Gas Inventories: Wetlands (eds. Hirashi, T., et al.). 354p. (Switzerland: IPCC Press (2014).

52. Mateo, M. A. \& Romero, J. Detritus dynamics in the seagrass Posidonia oceanica: elements for an ecosystem carbon and nutrient budget. Mar. Ecol. Prog. Ser. 151, 43-53 (1997).

53. Serrano, O., Mateo, M. A., Renom, P. \& Julià, R. Characterization of soils beneath a Posidonia oceanica meadow. Geoderma 185-186, 26-36 (2012)

54. Paling E. I., Fonseca, M., van Katwijk, M. M., \& van Keulen, M. Seagrass restoration in Coastal Wetlands: An Integrated Ecosystems Approach (eds. Perillo, G. M. E., Wolanski, E., Cahoon, D. R., \& Brinson, M.) 687-713 (Amsterdam: Elsevier (2009).

55. Mcleod, E. et al. A blueprint for blue carbon: toward an improved understanding of the role of vegetated coastal habitats in sequestering CO2. Front. Ecol. Environ. 9(10), 552-560 (2011).

56. Hansen, J. C. R. \& Reidenbach, M. A. Wave and tidally driven flows in eelgrass beds and their effect on sediment suspension. Mar. Ecol. Prog. Ser. 448, 271-287 (2012).

57. Oreska, M. P. J., McGlathery, K. J. \& Porter, J. H. Seagrass blue carbon accumulation at the meadow-scale. PLoS ONE 12(4), e0176630, https://doi.org/10.1371/journal.pone.0176630 (2017).

58. Berg, P. et al Dynamics of benthic metabolism, $\mathrm{O}_{2}$, and $\mathrm{pCO}_{2}$ in a temperate seagrass meadow. Limnol. Oceanogr. 64: 2586-2604 (2019). 
59. Berger, A. E., Berg, P., McGlathery, K. J. \& Delgard, M. L. Long-term trends and resilience of seagrass metabolism: a decadal aquatic eddy covariance study. Limnol. Oceanogr. https://doi.org/10.1002/lno.11397 (2020).

60. Rheuban, J. E., Berg, P. \& McGlathery, K. J. Ecosystem metabolism along a colonization gradient of eelgrass (Zostera marina) measured by eddy correlation. Limnol. Oceanogr. 59(4), 1376-1387 (2014).

61. Ferguson, A. J. P. et al. Oxygen and carbon metabolism of Zostera muelleri across a depth gradient - Implications for resilience and blue carbon. Estuar. Coast. Shelf Sci. 187(5), 216-230 (2017).

62. Potouroglou, M. et al. Sci. Reports 7, 11917, https://doi.org/10.1038/s41598-017-12354-y (2017).

63. Lefebvre, A., Thompson, C. E. L. \& Amos, C. L. Influence of Zostera marina canopies on unidirectional flow, hydraulic roughness and sediment movement. Continental Shelf Res. 30, 1783-1794 (2010).

64. Oreska, M. P. J., Wilkinson, G. M., McGlathery, K. J., Bost, M. \& McKee, B. A. Non-seagrass carbon contributions to seagrass sediment blue carbon. Limnol. Oceanogr. 63(S1), S3-S18 (2018).

65. Kollmuss, A., Lazarus, M., Lee, C., LeFranc, M., \& Polycarp, C. Handbook of Carbon Offset Programs: Trading Systems, Funds, Protocols and Standards. 210p. (London.: Earthscan (2010).

66. Forest Trends. Unlocking Potential: State of the Voluntary Carbon Markets 2017. 52p (Washington, D.C.: Forest Trends' Ecosystem Marketplace (2017).

67. Marbà, N. et al. Growth and population dynamics of Posidonia oceanica on the Spanish Mediterranean coast: elucidating seagrass decline. Mar. Ecol. Prog. Ser. 137, 203-213 (1996).

68. Orth, R. J. \& McGlathery, K. J. Eelgrass recovery in the coastal bays of the Virginia Coast Reserve, USA. Mar. Ecol. Prog. Ser. 448, 173-176 (2012).

69. McGlathery, K. J. et al. Recovery trajectories during state change from bare sediment to eelgrass dominance. Mar. Ecol. Prog. Ser. 448, 209-221 (2012).

70. Orth, R. J., Moore, K. A., Marion, S. R., Wilcox, D. J. \& Parrish, D. B. Seed addition facilitates eelgrass recovery in a coastal bay system. Mar. Ecol. Prog. Ser. 448, 177-195 (2012).

71. Fourqurean, J. W., et al. Field sampling of soil carbon pools in coastal ecosystems in Coastal blue carbon: methods for assessing carbon stocks and emissions factors in mangroves, tidal salt marshes, and seagrass meadows (eds. Howard, J., Hoyt, S., Isensee, K., Pidgeon, E., Telszewski, M.) 39-66 (Conservation International, Intergovernmental Oceanographic Commission of UNESCO, International Union for Conservation of Nature (2014).

72. Kennedy, H. et al. Seagrass sediments as a global carbon sink: Isotopic constraints. Global Biogeochem. Cycles 24, 1-8 (2010).

73. Howard, J., Hoyt, S., Isensee, K., Pidgeon, E., \& Telszewski, M. Coastal blue carbon: methods for assessing carbon stocks and emissions factors in mangroves, tidal salt marshes, and seagrass meadows (eds. Howard, J., Hoyt, S., Isensee, K., Pidgeon, E., Telszewski, M.) 15-24 (Conservation International, Intergovernmental Oceanographic Commission of UNESCO, International Union for Conservation of Nature. Arlington, Virginia, USA (2014).

74. Environmental Systems Research Institute. ArcGIS Desktop: Release 10.2. https://www.esri.com (2014).

75. Thomas, E. Influence of Zostera marina on wave dynamics, sediment suspension, and bottom boundary layer development within a shallow coastal bay. Thesis submitted to the University of Virginia 28-30 (2014).

76. McGlathery, K. J. Above- and Below-Ground Biomass and Canopy Height of Seagrass in Hog Island Bay and South Bay, VA 2007-2017. Environmental Data Initiative. https://doi.org/10.6073/pasta/09a0ce35bb3fc72113b5a16ad5b0d6bd (2017).

77. McGlathery K. J. Carbon and Nitrogen in Seagrass Tissue from Virginia Coastal Bays, 2010-2017. Environmental Data Initiative. https://doi.org/10.6073/pasta/b4d1f74041d329386591a32e9ea202b2 (2017).

78. Bates, D., Mächler, M., Bolker, B., \& Walker, S. Fitting linear mixed-effects models using lme4. J. Stat. Softw. 67(1); https://doi. org/10.18637/jss.v067.i01 (2015).

79. R Core Team. R: The R Project for Statistical Computing. https://www.r-project.org (2017).

80. Virginia Institute of Marine Science (VIMS). SAV in Chesapeake Bay and Coastal Bays. Available at: http://web.vims.edu/ bio/sav/ (2016).

81. McGlathery, K. J. Density of seagrass in Hog Island Bay and South Bay, VA 2007-2017. Environmental Data Initiative. https://doi. org/10.6073/pasta/5a6ea442cf59cabb3112bb634a968ae5 (2017).

82. Bahlmann, E. et al. Tidal controls on trace gas dynamics in a seagrass meadow of the Ria Formosa lagoon (southern Portugal). Biogeosci. Discuss. 11, 10571-10603 (2014).

83. Barber, T. R. \& Carlson, P. R. Effects of seagrass die-off on benthic fluxes and porewaterconcentrations of $\sum \mathrm{CO}_{2}, \sum \mathrm{H}_{2} \mathrm{~S}_{\text {, and }} \mathrm{CH}_{4}$ in Florida Bay sediments in Biogeochemistry of Global Change: Radiatively Active Trace Gases (ed. Oremland, R. S.) 530-550 (New York: Chapman \& Hall (1993).

84. Crill, P. M. \& Martens, C. S. Spatial and temporal fluctuations of methane production in anoxic coastal marine sediments. Limnol. Oceanogr. 28(6), 1117-1130 (1983).

85. Deborde, J. et al. Methane sources, sinks, and fluxes in a temperate tidal lagoon: the Archachon lagoon (SW France). Estuar. Coast. Shelf Sci. 89(4), 256-266 (2010).

86. Banerjee, K., et al Seagrass and macrophyte mediated $\mathrm{CO}_{2}$ and $\mathrm{CH}_{4}$ dynamics in shallow coastal waters. PLoS ONE e0203922; https://doi.org/10.1371/journal.pone.0203922 (2018).

87. Sansone, F. J., Rust, T. M. \& Smith, S. V. Methane distribution and cycling in Tomales Bay, California. Estuaries 21(1), 66-77 (1998).

\section{Acknowledgements}

P. Megonigal, M. Castorani, P. Wiberg, J. Porter, M. White, S. Emmett-Mattox, R. Orth, D. Wilcox, and S. Settelmyer provided advice or helpful feedback. J. Greiner and M.-L. Delgard provided access to data used in analyses. D. Peresta, M. Miller, and A. Schwarzchild provided field and/or lab assistance. We also want to thank the editor and two anonymous reviewers for their helpful feedback. Financial support was provided by Virginia Sea Grant, the University of Virginia Jefferson Scholars Foundation, and by National Science Foundation grants to the Virginia Coast Reserve Long-Term Ecological Research project (DEB-1237733, DEB-1832221). The Nature Conservancy owns and manages land areas in the Virginia Coast Reserve; permissions are not required to conduct research in subtidal areas, which are in the public domain. This project was completed at the University of Virginia. The authors declare no conflicts of interest.

\section{Author contributions}

M.P.J.O., K.J.M. and L.R.A. designed the study. M.P.J.O., L.R.A., A.C.B. and L.M. collected the data. All authors analyzed the data. M.P.J.O., K.J.M., L.R.A. and P.B. wrote the main manuscript text. All authors reviewed the manuscript.

\section{Competing interests}

The authors declare no competing interests. 


\section{Additional information}

Supplementary information is available for this paper at https://doi.org/10.1038/s41598-020-64094-1.

Correspondence and requests for materials should be addressed to M.P.J.O.

Reprints and permissions information is available at www.nature.com/reprints.

Publisher's note Springer Nature remains neutral with regard to jurisdictional claims in published maps and institutional affiliations.

(c) (i) Open Access This article is licensed under a Creative Commons Attribution 4.0 International License, which permits use, sharing, adaptation, distribution and reproduction in any medium or format, as long as you give appropriate credit to the original author(s) and the source, provide a link to the Creative Commons license, and indicate if changes were made. The images or other third party material in this article are included in the article's Creative Commons license, unless indicated otherwise in a credit line to the material. If material is not included in the article's Creative Commons license and your intended use is not permitted by statutory regulation or exceeds the permitted use, you will need to obtain permission directly from the copyright holder. To view a copy of this license, visit http://creativecommons.org/licenses/by/4.0/.

(C) The Author(s) 2020 